\title{
The humanitarian alibi: an overview and a redefinition
}

\author{
Matthew Bywater]
}

\begin{abstract}
This paper explores and illustrates the diverse manifestations of the phenomenon of the 'humanitarian alibi', drawing upon historical and contemporary cases of violent conflict in order to identify substitutionary phenomena by governments and international actors. It affirms the existence of substitution process where humanitarian aid intervention substitutes for the prevention and resolution of violent conflict and the protection of civilian populations. The paper argues for expanding the humanitarian alibi, however, to take into account how international aid intervention compensates for both the systemic neglect of conflict related crises and for the systemic harm that exacerbates and perpetuates these crises. It also challenges the suggestion that the humanitarian alibi phenomenon is the product of a bygone era, and finds that the use of aid as a substitute for peacemaking can co-exist alongside the use of aid as a direct component of international intervention.
\end{abstract}

Keywords: Humanitarian alibi, Humanitarian fig leaf, Band-aid, Substitution, Aid, Humanitarianism, Humanitarian action, International intervention, Military intervention

An alibi is traditionally understood as a story given to exonerate oneself from some accusation, e.g. 'I couldn't have done it because I was at my friend's house'. As such, it is an excuse/explanation offered to avoid blame and to justify oneself. The term 'humanitarian alibi' refers to a similar phenomenon. Entering into the discourse in the 1990s, it is loosely held to mean the use of humanitarian action by governments to conceal and counter criticisms for political inaction in response to violent conflict and civilian suffering. The humanitarian alibi has thus come to be a metaphor for a process of substitution: one where assisting populations with humanitarian aid subsitutes for protecting those populations. The terms 'humanitarian fig leaf' and 'Band-Aid' solutions have also appeared in the lexicon. ${ }^{1}$ In the academic literature, references are also found to the 'feigned engagement theory' and to the 'partial solution' and substitutionary

${ }^{1}$ For some references to the origins of the terms 'humanitarian alibi' and humanitarian 'fig leaf', see: (Jean 1993; Rieff 1997; Binet 2015, p. 56).

Correspondence: matthew.j.bywater@gmail.com

This article is a re-submission (NOHA-D-19-00040).

London School of Economics and Political Science, London, UK critiques (Slim 1997; Prendergast 1997). The term 'humanitarian alibi' has since largely receded from the prevailing discourse, replaced by terms such as the 'politicisation' and 'militarisation' of humanitarianism; these refer to the use of humanitarian (and developmental) action by governments as a direct component of international intervention, for example, the invoking of humanitarian justifications to justify warfare (e.g. 'humanitarian war'), 'integrated'/'coherent' approaches to political and aid-based intervention and the direct involvement of military forces in delivering assistance to populations.

In keeping with a practical perspective, this paper draws upon a range of a range of historical and contemporary cases of violent conflict in order to explore the diverse manifestations of the humanitarian alibi phenomenon. It considers those cases which are strongly associated with the phenomenon and those cases which are less associated. It takes into account both the systemic neglect of conflict-related crises but also the systemic harm that exacerbates and perpetuates these crises whenever they relate to the substitution process. It also 
considers the role played by the international humanitarian system in the substitution process.

The paper is neither a study in conflict formation (i.e. causes/drivers of conflict) nor a study in conflict resolution (i.e. solutions to conflict), only addressing these issues when they relate to the substitution process. Limited in scope, the paper is concerned with identifying and analysing these substitutionary phenomena by international actors in relation to violent conflict and civilian suffering. The focus on systemic neglect as well as harm is intentional and is due to the risk of portraying international intervention as a discrete act, that is, with a clear beginning and end. This definition of intervention, used in no small part of academia, falls short in a number of ways: it overlooks wider relations of interference in domestic societies, namely client-donor relations and economic interventions which form part of the background to conflictrelated crises; it suggests that the intervening states are not already implicated in the crisis in which they are intervening; and it presents a timeline of intervention beginning with an international humanitarian response and ending with the culmination of international military action (Bellamy 2003, pp. 330-1). In short, this understanding of intervention minimises the impact of harm and maximises the impact of neglect.

The study and analysis of the cases of conflict produces some particular findings. They affirm the existence of a substitution process, where international aid intervention substitutes for a political response to prevent and resolve violent conflict and to protect conflictaffected civilian populations. This process entails alibilike claims made by politicians to defend against accusations of political inaction and also to actively argue against taking political and military action to resolve conflict. However, evidence exists of aid compensating not only for systemic neglect but also for systemic harm. There is also evidence of the use of humanitarianism as a substitute for political action co-existing alongside the use of aid as a direct component of international intervention. These findings challenge the suggestion that the humanitarian alibi phenomenon is the product of a bygone era. They also underline the need for a more expansive concept of the humanitarian alibi phenomenon. Arguing for an expanded concept of the humanitarian alibi in this way, this paper thus seeks out and proposes a clear corrective to the dominant view of neglect..

This paper begins by presenting and analysing case studies of violent conflict that are strongly associated with the humanitarian alibi phenomenon (Bosnia-Hercegovina, Rwanda). It then moves on to other cases that are far less associated with the phenomenon (Kosovo, Afghanistan, South Sudan, Yemen). The case studies are presented chronologically, with occasional parallels drawn to more historical examples (e.g. the Spanish Civil
War, the Armenian Genocide) of substitutionary phenomena. The paper concludes with some final observations regarding the nature of the humanitarian alibi and also the role of the humanitarian system.

\section{Bosnia-Hercegovina}

\section{Part 1: An Alibi/Substitution}

Policymakers initially defined the conflict in BosniaHercegovina as borne out of centuries-old ethnic hatred (Feher 2000). ${ }^{2}$ In the words of the US Secretary of State, 'we don't have a dog in this fight' (cited in Holbrooke 1999, p. 27). Any involvement beyond providing humanitarian aid was to be avoided, in much the same way as British Prime Minister Winston Churchill had said, during the Spanish Civil War, to 'send charitable aid under the Red Cross to both sides, and for the rest-keep out of it and arm' (cited in Manchester 1989, p. 201). International policy aimed to contain the conflict within certain limits, namely preventing the fighting and population movements from spilling over international borders. This was accomplished by assisting populations to remain in situ and avoid becoming refugees. European refugee policy was particularly intransigent; governments did not hesitate to push people back at the height of the fighting and only one in ten displaced persons managed to find their way to Western Europe (Gow 1997, p. 111; Young 2001, p. 796).

Policymakers were primarily concerned with taking action for the sake of being seen to take action and also to maintain a semblance of international consensus. Essentially ad-hoc policies arose in the absence of a definitive solution. The safe area policy, as a Dutch parliamentary investigation of the Bosnian War determined, 'was designed to ensure that the tense relations within the [NATO] alliance...no longer persisted... [The plan] had less to do with the reality of Bosnia than with the need to restore transatlantic relations' (cited in Gibbs 2009, p. 154). A policy known as 'lift and strike', which envisaged using NATO air cover as part of a coordinated military campaign to end the fighting, was described by former British Prime Minister as follows: '[it] avoided committing American troops, yet maintained a high moral tone and a strident appearance of engagement with the crisis' (Major 1999, p. 540).

A peacekeeping mission called United Nations Protection Force (UNPROFOR) was deployed to the country and mandated to protect humanitarian aid convoys, the airlift into the Bosnian capital Sarajevo and UN-

\footnotetext{
${ }^{2}$ According to some accounts, the ethnic quagmire mind-set which existed in the State Department and the White House was due to Robert Kaplan's book Balkan Ghosts (1993). President Bill Clinton reportedly told others that, after reading Kaplan's book, he was struck by the deep historical roots of the Bosnian conflict which went on to shape his thinking on the limitations of intervention in that part of the world (Holbrooke 1999, p.22; Kaufman 1999).

${ }^{3}$ UN Security Council Resolutions 758 \& 819.
} 
designated 'safe areas'. The UN mandate requested that UNPROFOR avoid confrontation with the warring parties, only to engage militarily in self-defence. ${ }^{3}$ An UNPROFOR commander clarified that 'once a military force has deployed in a humanitarian aid role...it cannot be used to alter the military balance in a civil war, modify political goals of one party or another, or even attempt to enforce the passage of an [aid] convoy, for these are pure acts of war' (Rose 1995). The mandate to protect humanitarian operations not civilians was repeated by UNPROFOR commanders like a mantra (Rieff 1996). The protection extended only to the aid convoys, not to the civilian population, who were subject to large-scale violence, forced expulsion and mass killing even in the 'safe areas'.

A humanitarian relief effort was coordinated by the Office of the United Nations High Commissioner for Refugees (UNHCR), which included over 250 aid agencies (Ogata 2005, pp. 64-8). What became known as the 'official humanitarian script' (Andreas 2008, p. 12) acted as an indicator of international concern and determination vis-à-vis the armed conflict in Bosnia-Hercegovina. The typical response to pressure for conflict resolution was pledges to support the humanitarian response, either through funding increases or a greater focus on humanitarian issues in UN resolutions and international statements (see Barnett 1996, p. 154; Anonymous 1998; Young 2001, p. 788; Roberts 1993, p. 442; Morris 1998a). One UNHCR official observed that 'every time the question of settling the conflict came up, the donors responded by saying that they were going to give more money to the humanitarian effort' (cited in Lowell et al. 1994).

An internal review of the US humanitarian response to Bosnia-Hercegovina concluded that, at least in the case of the American government, "there was no grand "plan" to create a humanitarian alibi. Nevertheless, a humanitarian alibi did emerge'. It commented that 'there seems...to have been no concerted centralized policy to create a massive relief response [or] a humanitarian alternative to forceful political action' while adding that ' $a$ humanitarian response came to fill the vacuum left by the weak political and military policies of the US and other Western nations... [with] no strategic reflection on what goals this response was intended to achieve'. For example, some policymakers and other key actors truly believed that humanitarian action offered solutions to war and ethnic cleansing (Fawcett and Tanner 1999, pp. 5, 8, 53). With successes measured in humanitarian terms, the humanitarian approach became an end rather than a means to political progress (Andreas 2008, pp. 37, 42). The international effort to address the crisis became quantified, and the concern with measurement grew to

${ }^{3}$ UN Security Council Resolutions 758 \& 819. replace political action. ${ }^{4}$ One US official, recalling daily calls from the White House, put it in these terms: 'when the President...wants to know how many tons of lentils have been delivered that day, you know you have no [expletive] policy' (Fawcett and Tanner 1999, p. 29).

Neglect, even with undeniably malign consequences, is only side of a larger picture. The USA and other Western governments encouraged the Bosnian government to secede from the Yugoslav federation and declare independence, and then, firstly, played a decisive role in blocking measures that might have achieved this independence without war and, subsequently, disrupted international efforts seeking to end the conflict through diplomacy (Gibbs 2009, pp. 76-170). Having brought the country into existence, these governments then left the vulnerable civilian populations to their fate as violent conflict began to rage. The imposition of an arms embargo reinforced an already assymetrical division of power between the warring parties and rendered the civilians on the Bosnian Muslim-Croat side vulnerable to violence and forced expulsions by Bosnian Serb forces. An aid worker commented in the midst of the conflict that if one looks carefully, murky political reasons for [governments'] passive attitude can be found-the idea that events should be allowed to take their course in the Balkans so that a stable solution can be imposed by force' (Rufin 1993, p. 121). There is evidence to suggest that the American government knowingly declined to press for air strikes to protect the safe haven of Srebrenica, with a view to rendering a reality on the ground more conducive to a negotiated peace settlement (Hartmann 2015; VPRO 2015).

\section{Part 2: An Alibi/Substitution}

From acting as a minimum consensus, the humanitarian approach went on to impede further options to resolve the conflict. This was most vividly illustrated by the physical presence of the relief and peacekeeping operations, which impeded a military solution being imposed. One aid worker labelled this set of affairs as 'total humanitarianism': 'the logic of humanitarianism prevailed over the logic of a politics that did not dare exercise its prerogatives for fear of endangering humanitarian efforts in the field' (Destexhe 1993, p. 189; 1996, p. 56; 2000, pp. 108-9). ${ }^{5}$

The structure and mandate of UNPROFOR was designed to prevent coercive politico-military action from

\footnotetext{
${ }^{4}$ The international response mirrored earlier approaches to emergency settings in Africa, in particular, the short-termism of the relief agenda and the prioritisation of assistance over political objectives (Duffield 1994, pp.48-60; de Waal and Omaar 1994, pp.22-3).

${ }^{5}$ Total humanitarianism' is the reverse of 'total war', where humanitarian concerns are subjugated to the military objectives of the war.
} 
being carried out. Lightly armed UNPROFOR troops were deployed in vulnerable positions so as to convey the non-coercive nature of the peacekeeping force (Feher 2000, p. 70; Gordon 2000, p. 222). ${ }^{6}$ When air strikes were threatened, UN peacekeepers were repeatedly taken hostage by Bosnian Serb forces. A fierce reluctance prevailed among European-troop contributing countries to UNPROFOR and the UN not to depart from the non-coercive approach, for fear that the use of force would escalate military involvement, endanger peacekeepers and prevent the execution of the humanitarian mandate (Gordon 2000, pp. 218-9; Gow 1997, pp. 111-2). ${ }^{7}$ The mantra became to avoid anything that 'would compromise the humanitarian effort' (Rieff 1996, pp. 14-5). In the words of an UNPROFOR commander, 'when force is used, people start to die of starvation' (Rose 1995). By projecting the prospect of expanded conflict while peacekeepers and humanitarian workers were present and interruption of the humanitarian operation, the French and British governments were able to oppose coercive military action (Mooney 1995, p. 434; Destexhe 1993, p. 186) and the US Administration could justify its inability to take action by those governments' opposition: 'Washington had devised a way to gain domestic political benefit from tough talk about airstrikes, knowing it was shielded from acting' (Boutros-Ghali 1999, p. 87).

The UNHCR representative for the Balkans described his agency's principal role as 'human shields ${ }^{8}$ against any sort of international military action' (Mendiluce 1994, p. 17). Whether this positioning amounted to blackmail utilising the threat of starvation (Hoffman 1996, p.53), policymakers conflated cause and effect. That is to say, when it is the continuation of armed conflict that is producing severe humanitarian need, the termination of armed conflict is a necessary condition for obviating this need.

The historical parallels are striking with respect to the use of the humanitarian response to actively impede military intervention. During the Armenian Genocide,

\footnotetext{
${ }^{6}$ Troop-donating governments also resisted the creation of a small enforcement unit 'theatre reserve' that could have reduced this vulnerability, on the grounds of it leading to uncontainable military escalation (Gordon 2000, p.223).

${ }^{7}$ The threat posed to the humanitarian operation by robust enforcement mechanisms is a concern that comes up repeatedly in a recently released collection of documents from the Bosnian War (Owen 2013). See in particular the concerns of U.N. Secretary General Kofi Annan and UNPROFOR commander General Bernard Janvier, cited in (Annan 1999, pp.10, 104; Shawcross 2000, pp.90, 158). United Kingdom Parliamentary Hansard, House of Commons debates, 26 July 1993, Column 868

${ }^{8}$ The term 'human shields' actually mixes metaphors, since the arguments employed against military intervention concerned the disruption of humanitarian deliveries as opposed to aid workers being killed.
}

then-to-become American President Theodore Roosevelt railed against what he saw as a disingenuous use of US aid operations as an argument against opposing the genocide militarily: 'we are guilty of a peculiarly odious form of hypocrisy...to allow the Turks to massacre the Armenians and then solicit permission to help the survivors, and then to allege the fact that we are helping the survivors as a reason why we should not follow the only policy that will permanently put a stop to such massacres is both foolish and odious' (cited in Morison 1954, pp. 1317-8).

\section{Part 3: Substitution of Responsibility}

By default or by design, the framing of the Bosnian conflict as a 'humanitarian' rather than a political crisis permitted governments to excuse themselves of further involvement. The US Secretary of State is on record stating candidly that 'if you define it as a humanitarian situation, then your options are really much different than they would be in [other] places'. ${ }^{9}$ Focusing UNPROFOR on protecting the humanitarian operation rather than civilians had a similar effect. The UN was able, by insisting that 'success should be measured in light of the goals the organisation sets itself, to repudiate criticism of its performance in Bosnia-Hercegovina; the UN SecretaryGeneral informed an UNPROFOR parade after the Srebrenica massacre that they had performed admirably, while the memoirs of UNPROFOR commanders emphasise their impartial mandate and the difficult job they carried out (Rieff 2002, pp. 117, 158).

Abrogation of responsibility-in this case, for resolving conflict and protecting civilians-by definition, involves apportioning it to other actors: '[as long as] responsibility is [not] assigned appropriately, accountability cannot be accurately defined' (Macrae et al. 1996). This produces loses as well as winners, as humanitarian actors find themselves the object of unrealistic expectations and blamed for outcomes far beyond their reasonable capacity. French President François Mitterrand was feted by a French newspaper as 'Président sans Frontières' for his inauguration of the Sarajevo airlift (Dachy 2004, p. 32). At the same time, polls carried out found that large majorities of Europeans believed humanitarian organisations to be better suited to respond to crises and prevent conflicts than national governments or international institutions (cited in Brauman 1996, 2004, p. 414). Former International Committee of the Red Cross (ICRC) President Cornelio Sommaruga warns that confusion of this sort arises when the humanitarian alibi passes unnoticed by the general public (Lorenzi 1998, p. 54).

\footnotetext{
${ }^{9}$ US Congressional Record Volume 140, Number 15, 1994.
} 
Part 4: The Role of the International Humanitarian System Humanitarian agencies bear responsibility for their role in humanitarianizing the conflict. Agencies reported the potential for massive death in a long series of 'winterscares'. These urgent calls to respond to humanitarian needs furthered the view that Bosnia-Hercegovina was a humanitarian problem that could be addressed if sufficient resources were directed (Fawcett and Tanner 1999, p. 49).

Journalist David Rieff observed that 'by highlighting the little successes, [humanitarians] helped to obscure the fact that no real progress was being made' (1996, p. 123) and to diminish the level of public demand to end the conflict. The relationship between humanitarian and political action was inverse: the stronger the humanitarian effort, the more effective substitute for resolving the conflict offered (2002, p. 137). One example is the airlift into Sarajevo, which replaced dramatic images of persecution with a showcase of humanitarian action, distracting the attention of the media and policymakers from ethnic cleansing and concentration camps and rendering the siege of the city palatable to Western audiences. Indeed, immediately after the airlift's operationalization, Western governments ended their insistence on a ceasefire and the withdrawal of heavy weaponry from Sarajevo (Andreas 2008, pp. 35, 72; Fawcett and Tanner 1999, pp. 26-9). Sections of the British media likewise exaggerated the importance of the British military contingent in UNPROFOR, distracting from the failure to stop the war and reducing public demands for action to terminate the war (Vaux 2001, p. 210). Scant attention was paid to what 'humanitarian' actually implied, with one newspaper headline stating: 'NATO may send in 100,000 troops to cover aid convoy' (The Independent 1992).

Evidence also suggests that ICRC and UNHCR at times 'balanced' their public statements about the atrocities being enacted, thereby distorting the relative culpability of the parties to the conflict. This painted a picture of violence committed by all parties in equal measure (see Kent 2003). Aid worker Fiona Terry once contended that an overzealous commitment to impartiality and neutrality, by 'refusing to make a judgement about who is right and wrong[,]...assumes a legal and moral equality between oppressors and their victims' (2002, p. 22). When this equality does not correspond to the reality on the ground, agencies foster a false moral equivalence with consequences such as, in this case, legitimising a depiction of mindless ethnic violence and bolstering a noninterventionist case.

Another difficult question faced humanitarian workers, specifically, the extent to which their participation in the international response left them less willing to 'rock the boat' and expose the failings of this response. The head of Oxfam-GB David Bryer mused whether an increasingly cosy relationship, both in terms of funding and accepting military protection, inhibit [ed] the freedom of NGOs to critique the UN performance?' (Bryer 1996).

\section{Rwanda}

\section{Part 1: An Alibi/Substitution}

In the years leading up to the Rwandan genocide, Rwanda was one of the largest beneficiaries of international development aid and held a very positive and widely accepted image as a model of development. An apolitical image-a generic and also exemplary developing country-told by international agencies was used to construct Rwanda as a 'development problem' that was being solved by developmental aid (Uvin 1998, pp. 4046). As violence and human rights abuses became government policy, international actors were congratulating Rwanda for its developmental successes and calling on it to 'improve its capacity to design and implement development projects' (ibid, p. 89). Rwanda received an aboveaverage amount of official development aid compared to other African and developing countries. As governmentsponsored violence and rights abuses rose in the 1990s, development aid increased further-albeit for separate reasons: massive increases in 'program aid'10 as part of structural adjustment-inspired policy changes-and military support from most countries continued and from at least one increased significantly (ibid, pp. 41, 87, 236).

\section{Part 2: An Alibi/Substitution}

A humanitarian script defined the modus operandi for international engagement towards the Rwandan genocide and the subsequent crises in the Great Lakes region. The Joint Evaluation of Emergency Assistance to Rwanda (JEEAR) observed that the 'readiness with which the international community appears prepared to fund humanitarian assistance programmes contrasts with the lack of concerted efforts to devise coordinated political solutions to the crisis' (Borton et al. 1996, p. 12). It continued: 'the essential failures of the response of the international community to the genocide...were...political...Humanitarian action substituted for political action' (Eriksson 1996, p. 10).

When presented with requests by humanitarian organisations for decisive action to stop the genocidal killings, Western government officials stressed their contributions in humanitarian aid and made pledges for increased funding. When French President Francois Mitterrand was asked publicly what he was doing to stop

\footnotetext{
10‘Program aid' is money given without a specific purpose to facilitate or induce the often painful policy change associated with the structural adjustment scheme. This is in contrast to the more ordinary 'project aid' which is donated for specific inputs in a previously agreedon project (Uvin 1998, p. 87).
} 
the Rwandan genocide, his response was to allocate funds to two aid agencies. Two civilian officers on the Africa desk in the Office of the French President, in a meeting with Médecins sans Frontières (MSF) representatives who demanded that French government officials pressure their allies in the Rwandan government to stop the killings, responded by offering to allocate an additional three million francs to aid organisations (Terry 1998, p. 139; Le Pape and Bradol 2017, pp. 40-1). British Prime Minister John Major, responding in writing to a consortium of aid agencies who had requested that urgent action be taken to prevent the killings, such as a $\mathrm{UN}$ force to protect civilians seeking refuge in safe areas, wrote that 'we are making a substantial contribution to the humanitarian relief effort' (1994).

As the genocidal killings were underway, the USA and UK governments insisted initially that Security Council statements omit the word 'genocide'. State Department lawyers expressed concern that a genocide finding could commit the US government to take action. A National Security Council staffer reportedly asked how using 'genocide' might affect Congressional elections later in the year. The UK ambassador to the UN opposed the label 'genocide' out of concern for delegitimising the UN if it did not then intervene (Power 2002, pp. 359-61; Wheeler 2000, p. 226; Barnett 2002, p. 135; Jehl 1994; U.S. Office of the Deputy Assistant Secretary of Defence for Middle East/Africa Region 1994).

Any narrative of malign neglect is again partial and misleading: 'it is not the case that foreign powers were absent, but rather that their involvement was entirely limited to serving their own ends' (Melvern 2004). Loyalty to old friends was a consistent feature of French policy in Africa, wedded to notions of the prestige of La Francophonie and global influence (Chipman 1989). The French government provided military training and equipment (including embedded officers and soldiers) to the Rwandan government for years before and during the genocide, in contravention of a UN arms embargo (see Prunier 1995; Bayart and Massiah 1995; HRW 1999). Thus, the political action taken did not simply leave the endangered civilian populations to their fate; it actively contributed to the endangering.

A small peacekeeping mission named the United $\mathrm{Na}$ tions Assistance Mission in Rwanda (UNAMIR) was in place prior to the genocide and mandated to 'contribute to the security of the city of Kigali within a weapons-secure area established by the parties in and around the city....[and] to assist in the coordination of humanitarian assistance activities in conjunction with relief operations. ${ }^{11}$ Although the Arusha Accords had envisaged a force that would help secure Kigali by searching arms caches and

\footnotetext{
${ }^{11}$ UN Security Council Resolution 872.
}

neutralising militias, the UN Security Council established UNAMIR with a significantly more restrictive mandate. UNAMIR was sanctioned as a mission that could only contribute to security in Kigali within the weapons-secure area and to monitor the ceasefire (UN 1996; AU 2000, pp. 45, 98; Adelman and Suhrke 1996, p. 90).

As the genocide began to unfold, the killing of ten Belgian peacekeepers created a political surge to withdraw. A UN Security Council resolution reduced the size of UNAMIR to a skeleton crew of 250 soldiers and redefined its role as acting as an intermediary between the warring parties, monitoring and reporting on developments in the country including the safety of civilians under UNAMIR protection and assisting in the resumption of humanitarian relief operations. This resolution also 'appeal[ed] to the international community to provide increased humanitarian assistance commensurate with the scale of the human tragedy in Rwanda. ${ }^{12}$ The UNAMIR force, having been drastically reduced in size, was unable to expand its efforts to protect Tutsi civilians taking refuge in churches and schools and its efforts to protect and rescue civilians were confined to those civilian populations already in the few areas under UN control. The Security Council later conferred a new mandate on UNAMIR-guaranteeing the protection of endangered civilians in Rwanda-and authorised it to use force to protect threatened persons and sites. ${ }^{13} \mathrm{~A}$ stronger mandate was later adopted by the Security Council and UNAMIR reconfigured into UNAMIR-II, but this force was deployed only after the genocide had ended. The deployment of an African force to enhance UNAMIR stalled with no additional men made available for want of equipment from Western countries. The UN was prevented for weeks in moving armoured personnel carriers to Rwanda, as The Pentagon and the UN reportedly negotiated over details such as whether to buy tank-like or wheeled vehicles and whether the UN should buy or lease the vehicles (Adelman and Suhrke 1996, p. 41; Borton et al. 1996, pp. 59-60; Eriksson 1996, p. 18; Burkhalter 1994/5, pp. 47, 50-3).

The relationship between UNAMIR's involvement in delivering humanitarian assistance and providing security was not one of substitution. A cable sent by UNAMIR head Romeo Dallaire to UN Security members two weeks into the genocide read as follows: 'in actual fact, there is little that we are doing at the present time except providing security, some food and medicine and a presence. Humanitarian assistance has not really commenced' (cited in Carlsson et al. 1999, p. 21). The discrepancy here is between promise and actual commitment.

\footnotetext{
${ }^{12}$ UN Security Council Resolution 912.

${ }^{13}$ UN Security Council Resolution 918.
} 
A clear instance of the assistance-protection substitution is seen in the French-led military intervention Operation Turquoise. Prior to the deployment of UNAMIR-II, the Security Council authorised Operation Turquoise, a French-led military intervention, to assist in humanitarian efforts and protect refugees, displaced populations and at-risk civilians. The Resolution stressed the 'strictly humanitarian character of this operation which shall be conducted in an impartial and neutral fashion' and did not employ the term 'genocide', instead referring to the 'humanitarian crisis in Rwanda'. ${ }^{14} \mathrm{Nei}-$ ther the UN mandate for Operation Turquoise nor the objectives set by the French government for the mission included taking action to stop genocidal killings, to screening or arrest suspected genocidaires, or even to disarm soldiers despite the very concept of a safe humanitarian zone implying a demilitarised area. The military operation enabled an increase in humanitarian assistance in south-west Rwanda and managed to protect around 14,000 threatened civilians, but killing of civilians continued in the safe zone in areas away from Turquoise forces (Borton et al. 1996, pp. 12, 65; Adelman and Suhrke 1996, p. 55).

The French troops deployed as part of Operation Turquoise also facilitated the protection and retreat of the Rwandese army and government from the safe zone; strong pro-Rwandese government circles in the French Ministry of Defence saw the intervention as an opportunity to assist the Rwandan army (ibid, pp. 54-6; de Saint-Exupery 1998; IHT 1994). As such, the mission reflects the more well-known practice of professing 'humanitarian' intent to pursue foreign policy objectives (Terry 2002, p. 193) as well as the use of humanitarianism as an alibi for inaction to protect civilians.

\section{Part 3: An Alibi/Substitution}

The winning of the Rwandese civil war by the Tutsi-led Rwandese Patriotic Front (RPF) and the end of the genocide was followed a massive population movement, as a large segment of the Hutu population fled Rwanda into neighbouring countries. The remnants of the Hutu-led former Rwandese government quickly seized control of the refugee camps which had formed in Tanzania and then Zaire and established themselves a sanctuary there, which they used to inflict violence on the civilian population in the camps and to launch attacks in Rwanda proper.

The UN Secretary-General called upon the international community to address the 'genocide of hunger, thirst and disease' that was unfolding in the refugee camps, and also issued proposals for deploying UN troops to establish security in the camps and to separate

\footnotetext{
${ }^{14}$ UN Security Council Resolution 929.
}

military elements from the refugees (Boutros-Ghali 1994a, para 26; 1994b). These proposals went unheeded by UN member states. Instead, what materialised was US-led Operation Support Hope. Established as a strictly humanitarian operation with no peacekeeping role and no mandate to arrest suspected genocidaires, the operation engaged in a 'war against cholera' and did not attempt to address the high levels of insecurity (Borton et al. 1996, pp. 69-70, 190; Terry 2002, pp. 172-3). Western governments and UN officials congratulated themselves for the humanitarian accomplishments of the operation and again claimed that a forceful intervention in the camps would put the lives of humanitarian workers at risk (Feher 2000, pp. 107-8). However, amidst threats by the new RPF-dominated Rwandan government to take action against the remnants of the former regime active in the camps, the American Administration signalled to that it would not oppose such an action if taken (Borton and Eriksson 2004, p. 146).

Responsibility failed to be discharged in the following ways. The belligerents failed in their responsibility to respect humanitarian law, specifically the distinction between combatants and non-combatants. Governments failed in their responsibility to uphold and enforce humanitarian law (Terry 2002, p. 207).

\section{Part 4: Substitution of Responsibility/The Role of the International Humanitarian System}

In this situation of unmet responsibility, humanitarian agencies came to be internationally criticised and accused of 'feeding the killers' (Stockton 2002, p. 34). Humanitarian workers again faced difficult questions regarding their role in the overall equation, all the more so given the massive amount of funding which flooded in the refugee camps to support aid work (a phenomenon since known as the 'Humanitarian Circus'). The pressure to be present in such a high-profile crisis was enormous: the public relations' aspect of being seen to do something as well as the organisational rewards (profile and money) of being involved (Jones 1997, p. 32).

\section{Kosovo}

\section{Part 1: An Alibi/Substitution}

The initial policy response to the Kosovo conflict was strongly reminiscent of the policy response in BosniaHercegovina. The conflict was initially depicted by Western governments in terms of humanitarian assistance and reconstruction (Morris 1999, p. 18; Feher 2000, p. 166; Economides and Berdal 2007, pp. 224-6). A medium-scale war-time emergency relief convoy operation, developed from a low-level humanitarian assistance programme on the ground, was endowed with the 'UN-imprimatur' (Stoddard 2006, p. 164). Internal UN communication drew parallels with the shortcomings of 
the international approach to Bosnia-Hercegovina: 'we are facing [an] all too familiar challenge....an international community that two months ago was saying that Kosovo would not be allowed to become another Bosnia seems to be at a loss as to how to prevent very similar human suffering...Humanitarian action will remain the focus of the international community's attention....The international community has consensus on only one declared objective...There is a strong wish to contain the problem, and its victims, within the region' (Morris 1998b).

A Contact Group meeting early on in the conflict played down the violence and produced proposals for deployment against any spill-over of the conflict into neighbouring States and for NATO to guard the Albanian border. ${ }^{15}$ With the objective of halting the growing conflict and restraining the protagonists in the shortterm, an unarmed Organisation for Security and Cooperation in Europe (OSCE) monitoring mission ${ }^{16}$ was established. Strict instructions were issued requiring the monitors to observe fighting from a distance, not assist wounded combatants or carry out direct interventions to halt fighting or destruction of property. The OSCE monitors were slow to arrive on the scene and poorly briefed and ultimately failed to restrain the protagonists or provide any meaningful protection to the civilian population (Pettifer 2012; Byrnes 2013; Dziedzic 2006, p. 325; Morris 2004, pp. 113-4). UN Secretary-General Kofi Annan was warned by his staff that 'with the accumulation of such extra tasks, the KVM could face the same problems as UNPROFOR in Bosnia' (cited in Shawcross 2000, p. 21).

\section{Part 2: An Alibi/Substitution}

NATO governments later launched an aerial bombing campaign against Serbia/Federal Republic of Yugoslavia with the stated aims of enforcing a semi-negotiated peace agreement, ending the repression of civilians and averting a 'humanitarian disaster'. The fate of the Kosovo Albanian refugees being expelled by Serb/Yugoslav forces then became the public justification and raison d'être for the military intervention. ${ }^{17}$ British Prime Minister Tony Blair referred explicitly to the refugees and the importance of their return: 'it is in the aid of these innocent victims of Milosevic, that NATO is engaged in this campaign to get his troops out and the refugees back home in safety' (Blair 1999). A range of Western politicians and military officials employed the terms 'humanitarian bombing' and 'humanitarian war'

\footnotetext{
${ }^{15}$ The NATO plan would have done absolutely nothing to protect Albanian civilians already subject to occasional shelling from Kosovo in border regions (Pettifer 2012, p. 135).

${ }^{16}$ The Kosovo Diplomatic Observer Mission/Kosovo Verification Mission.

${ }^{17}$ List of expanded objectives issued at NATO summit on 23-24 April 1999, cited in Roberts (1999, p. 103).
}

(Havel 1999; Roberts 1999, p. 103; Slim 2001, p. 332). Shortly after the war, US President Bill Clinton declared that 'the care of victims is important but not enough. We should work to end the violence' (Clinton 1999).

A number of observers took note of a compelling turning point: humanitarian justifications were no longer being used to excuse political and military inaction, but to justify and provide a moral warrant for war:

Humanitarianism had served in Bosnia as a pretext for the refusal of the great powers to intervene. In Kosovo, humanitarian efforts were deployed for the opposite purpose (Rieff 2002, p. 197)

The "humanitarian" motives invoked to rule out military intervention suddenly gave way to a very different usage of humanitarianism when NATO forces bombarded Serbia and occupied Kosovo... In this new context, Western powers certainly did not need to display their humanitarian preoccupation in order to stave off accusations of pusillanimity...However, references to humanitarian concerns did not disappear from their rhetoric-quite the contrary...The same humanitarian solicitude that had dissuaded Western leaders from taking sides and committing their own troops...was now being held as the main reason to designate the guilty party and get military involved' (Feher 2004, pp. 782-3)

The response to the expulsions...was in some ways the mirror image of that during the war in Bosnia... [where] humanitarian action had substituted for political will. For Kosovo, political will had been exercised (Morris 2007, p. 367)

A closer examination, however, reveals some constants. Most notably, the intervening governments refused to tolerate any casualties of their armed forces, and ruled out a ground-invasion from the beginning (Clinton 1999). Military instruments with proven effectiveness at engaging groundtargets-for example, those undertaking expulsions of civilians-such as American anti-tank Apache helicopters, A-io 'Warthogs' and British Royal Air Force Harriers, were never deployed due to their vulnerability and high projected attrition rate amid severe disagreements over the level of acceptable risk. ${ }^{18}$ Reliance on air strikes as the sole military means left NATO unable to influence events on the ground and

\footnotetext{
${ }^{18} \mathrm{~A}$ combination of bureaucratic delays and insistence on safety guarantees was given. The Apache helicopters required almost a month of 'pre-deployment preparations' despite the vast expenditure committed to maintaining their instantaneous 'readiness'. The U.S military then insisted that the Apaches be supported by heavy rocket barrages to suppress Serb anti-aircraft weapons, thereby creating a significantly greater logistical load and further delay (Luttwak 1999, p. 41; Priest 1999).
} 
was soon faced with the largest refugee flight in Europe since World War II as Serb/Yugoslav forces embarked on a campaign of mass expulsion of the Kosovar population. NATO's Supreme Commander openly conceded that 'air power alone cannot stop paramilitary murder on the ground' (NATO 1999). Either from the ground or from the air, no protection was provided to the Kosovar civilian population.

Responding to a UNHCR request for assistance amid an impending catastrophe for refugees trapped at the Macedonian border, NATO took on relief agency functions such as building and operating refugee camps, storing and transhipping aid cargo, distributing relief and transferring refugees. Following on from this, Western governments became directly involved in humanitarian initiatives with non-governmental organisations (NGOs) in the refugee camps (Huysmans 2002, p. 603; Balanzino 1999; Morris 1999, p. 19; Ogata 2005, pp. 147-8; Rieff 2002, p. 204; Hammerstad 2014, p. 245).

This military involvement in humanitarianism was admittedly a consequence of military action, not inaction (Pugh 2000, p. 232). That is to say, it represented in no small part a form of damage control: counteracting charges of having precipitated the flight of expelled populations from Kosovo. One NATO official described the objectives of a NATO force with an explicitly humanitarian mission as 'to house the refugees [and] to maximize a positive media image of NATO to counteract the negative effects of NATO's unpopular bombing campaign' (cited in Tomlinson 2000, p. 17). But military action is a matter of degree, rather than there being binary constructs of action versus inaction. As a result of inaction on the military front of ground terrain-where large-scale expulsions of civilians had been initiated and persecution had massively intensified-those abuses were able to continue. Crucially, treating the humanitarian consequences of the conflict (in this case, a refugee outflow) took precedence over and substituted for military intervention in Kosovo to protect trapped civilians and put a stop to the forced expulsion of populations (in other words, to directly tackle the cause of the refugee exodus).

International Crisis Group also warned of the risks of 'humanitarianizing' the crisis: 'the rush to provide food and shelter to the refugees...draw $[s]$ attention away from events inside Kosovo and the urgent need for a political and military strategy that addresses the root causes of the conflict...A real danger here is that...NATO countries will feel they have done enough... and will not summon the resolve...necessary to guarantee the ethnic [Kosovo] Albanians' safe return' (International Crisis Group 1999, pp. ii, 5). On the military side, senior figures in the British military voiced internal criticism about the decision to involve contingents in building and helping run refugee camps, the reasoning being that this might fix and divert military resources away from a future ground invasion into Kosovo. ${ }^{19}$

On several occasions at NATO press conferences when such pressure was at its highest, military involvement in the humanitarian relief operation and the underlying humanitarian rationale for the entire military intervention were stressed in response (see Clinton 1999; Schoenberger-Orgad 2007, pp. 169-70, 202-3, $255,276-81)$. In this way, military involvement in humanitarianism served to off-set pressure for sending ground troops to Kosovo. An Inter-Agency Review of US Government Humanitarian Programs concluded that, despite the government's failure to overcome its reluctance to undertake ground-based civilian protection, 'the goals of NATO's...intervention were realised' through the military-humanitarian response and that 'the US humanitarian effort was critical to the success of US policy' (US State Dept. 2000).

\section{Part 3: An Alibi/Substitution}

Low-level biut persistent and increasingly systematic violence continued for up to 2 years in post-war Kosovo (OSCE 1999; Boyle 2010) during which tens of thousands of Serb and Roma were forced to flee into ethnic enclaves. Despite the increasingly organised aspects and systematic nature of the violence, senior Western leaders and members of the international administration presented it as 'mindless violence' or the mere product of revenge which should be tacitly accepted as such. The following statement made by US Secretary of State Madeleine Albright best epitomises this minimisation of the violence: 'after all that has happened, we do not expect the rival communities in Kosovo to immediately join hands and start singing folk songs. ${ }^{20}$ A senior NATO military official conceded privately that the ethnic homogenisation taking place in Kosovo 'solved the problem' by removing the presence of suspected Serb militias. ${ }^{21}$

Governments were slow to provide the United Nations International Administration Mission in Kosovo (UNMIK) with a sufficient number of international police officers, many of whom were of poor quality and had to be sent home. Responsibility for providing security and enforcing law and order fell to the international peacekeeping mission Kosovo Force (KFOR). KFOR, although it deployed and built up an operating structure far more swiftly (see Hochschild 2004, pp. 290-2; Erlanger 2000; Blumi 2005, pp. 16-7), failed by any meaningful account to counter the violence against minorities. The approach adopted by KFOR seemed

\footnotetext{
${ }^{19}$ Telephone interviews with Major General (Retired) Tim Cross CBE, November 2014 and February 2016.

${ }^{20}$ Building a Europe Whole and Free', event sponsored by the Bohemia Foundation, Prague, Czech Republic. 7 March 2000.

${ }^{21}$ Interview with a UK-based academic, January 2015.
} 
initially guided by the same 'zero-risk' principle; confrontations were carefully avoided, patrols reduced to the essential and troop visibility minimised, and the general/total disarmament of the Albanian population avoided (Pekmez 2001, pp. 15-7). During the first year, officials from the US administration acknowledged privately that the overriding priority was to avoid American casualties and keep Kosovo out of the news during an election year (Perlez 2000).

While security and order were what was first and foremost needed, UN administrators presented healthcare and material assistance as a priority, with the violence relegated into the background. Despite the absence of any epidemic, malnutrition or acute crisis, massive financing at approximately a billion euros a year-the largest budget the European Union had ever distributedflooded into the province. Meanwhile, KFOR contingents engaged in humanitarian activities, offering providing mobile clinics and free drugs as part of hearts and minds campaigns ${ }^{22}$ at a time when UNMIK officials were declaring it impossible to 'put a soldier on guard duty in front of every Serb's door' (Dachy 2001, pp. 120-7; 2004, p. 34).

\section{Afghanistan}

\section{Part 1: An Alibi/Substitution}

Humanitarian norms are often framed in terms by making explicit connections between humanitarian efforts and values such as democracy and human rights; the military intervention in Afghanistan was framed by its proponents as 'emancipation' (Labonte 2003), who presented the oppressive nature of the Taliban regime and its treatment of women, in addition to saving the Afghan population from famine and easing refugee returns, as arguments in favour of liberation (Hehir 2008, p. 57). A wide range of rhetorical commitments to the long-term welfare of the Afghan people and nation were issued by British and American leaders (CNN 2001, 2002; Purdum and French 2002; The Guardian 2001a, 2001b; Straw 2001). British Prime Minister Tony Blair declared that 'we will not walk away from [ordinary Afghans] once the conflict ends... We will stand by them and help them to a better, more stable future....That is our pledge' (cited in Irish Times 2001). In a private memo to US President George W. Bush, he wrote that 'how we finish in Afghanistan is important...If we leave it a better country, having supplied humanitarian aid and having given new hope to the people, we will not just have won militarily but morally... [W] shall have given regime change a good name' (Blair 2001).

\footnotetext{
${ }^{22}$ Telephone interview with aid worker based in northern Kosovo, August 2014.
}

After having overthrown the Taliban, the intervening Western governments made it clear that the priority was the pursuit of Taliban and al-Qaeda remnants. As of 2003, international spending on Afghanistan went overwhelmingly to military operations against al-Qaeda and the Taliban remnants (84\%), while the remaining amount went to ISAF (4\%), humanitarian assistance (9\%) and reconstruction (3\%) (CARE 2002, p. 5).

The US Administration spokesman stated that the [US] will participate in helping secure the future of Afghanistan. First and foremost is through our military presence...to fight a war. The security of Afghanistan will best be obtained... [by] having eliminated the alQaeda and the Taliban...The purpose of the troops there is to fight and win wars. And in the process...it certainly has made Afghanistan a safer country...The President continues to believe the purpose of the military is to be used to fight and win wars, and not to engage in peacekeeping, ${ }^{23}$ adding, 'having said that, the [US] is committed to the long-term of Afghanistan, including its security and safety. That's one of the reasons [it] is providing the amount of [funding and training] aid we are to Afghanistan' (White House 2002; AP Project 2002). The spokesman added that 'the [US] has been the largest donator of food to the people in Afghanistan. We continue in that role. When you talk about security, certainly having the people fed is part of security (White House 2002).

The Pentagon insisted that the word 'assistance' be inserted into the International Security Assistance Force (ISAF), underlining its purpose of assisting the Afghan security forces and detracting from any obligation to provide security for the Afghan populace. The British Defence Secretary also emphasised that ISAF was an 'assistance' mission to the central Afghan government rather than a peacekeeping one (Dobbins 2008, pp. 102-3; Nicoll 2002).

For several years, ISAF remained confined to the capital Kabul. The US Department of Defence was firmly opposed to the creation of a peacekeeping force and the expansion of ISAF on the grounds that its presence would 'confuse the battlefield' and obstruct military operations against Al-Qaeda and Taliban remnants (Kampfner 2003, p. 146). With a view to tracking alQaeda and Taliban operatives, US forces made alliances with regional powerbrokers/warlords to maintain nongovernmental militias which plagued the population and contributed to the generalised insecurity across the country (Lockhart 2011, pp. 262, 265). The UN Human Rights Representative for Afghanistan sounded the alarm

\footnotetext{
${ }^{23}$ There is an irony here that, as this section details this traditional view of the military - fighting wars and not engaging in peacekeeping - led to military involvement in the delivery of aid.
} 
just a few months after the overthrow of the Taliban, declaring that 'Afghans are living in a vacuum as authorities are finding it difficult to keep the peace between rival warlords and control crime' (cited in AP 2002).

\section{Part 2: An Alibi/Substitution (Humanitarian Relief- Reconstruction)}

Shortly after the 9/11 terrorist attacks, President Bush had announced a reversal of the long decline in the US aid budget on the grounds that 'the advance of development is a central commitment of American foreign policy. We work for prosperity and opportunity...because they help defeat terror...as the civilised world mobilises against the forces of terror, we must also embrace the forces of good. By offering hope where there is none, by relieving suffering and hunger where there is too much, we will make the world not only safer but better' (cited in Dietrich 2005, p. 287).

Old habits continued to die hard. The long-standing scepticism within the US Republican Party about the ability of the international aid establishment to design and deliver a sound peace-building strategy remained undiminished; 2 years on from the invasion of Afghanistan, such a strategy appeared to be as elusive as ever (Stockton 2004, p. 29). Western governments showed little inclination for any involvement beyond providing assistance, such as long-term recovery. The promise of a 'Marshall Plan' for Afghanistan to reconstruct the country and bolster security never materialised. The second donor conference on Afghanistan following the overthrow of the Taliban pledged only $\$ 8.2 \mathrm{bn}$ against the Afghan government's bid for $\$ 27.5$ bn. By late 2003/early 2004, the majority of disbursed funds had been spent on humanitarian relief rather than reconstruction (Christian Aid 2004, p. 41; IMF 2003, p. 16; Rubin et al. 2004, p. 10). ${ }^{24}$ One analyst observed that 'donors were reluctant to fund reconstruction and development rather than emergency programs, which were less attractive to their publics' (Minear and Smilie 2004, p. 102). From 2002 to 2005, only $\$ 3.3$ billion of the $\$ 13.4$ billion pledged was spent on reconstruction and development (Barakat et al. 2008, p. 46). In 2006, Afghanistan suffered from donor fatigue and received a lower proportion of aid per capita than other post-conflict nations (ACBAR 2006, p. 1).

\footnotetext{
${ }^{24}$ This side-lined calls by the Afghan government for early attention to activities that would have provided short-term income and long-term benefits in favour of in-kind distributions (Leader and Atmar 2004, p. 175).
}

\section{Part 3: An Alibi/Substitution (PRTs-ISAF)}

The principal expression of militarised aid in Afghanistan was the Provincial Reconstruction Teams (PRTs): 'military structures... which also include donor representatives and civilian specialists with responsibilities for relief, reconstruction, development and security' (Donini et al. 2008, p. 21). The PRTs undertook smallscale reconstruction projects and other provision of assistance for the purposes of winning hearts and minds.

The militarisation of aid in Afghanistan and elsewhere has provoked most controversy for 'blurring the lines' between military and civilian humanitarian actors (see Donini 2009; McHugh and Gostelow 2004; Weissman 2004; Jackson 2010). The contention that the militarisation of aid has substituted for the provision of security has arisen with far less vigour.

The PRT mandate was restricted to negotiation, intelligence-gathering, reconstruction and other hearts and minds-related work at the expense of disarming militias/demobilisation of fighters, intervening between fighting factions, controlling small-scale criminality and protecting civilians (O'Brien and Barker 2003, p. 20; O'Brien 2005, p. 214; Thier 2006, p. 500). An earlier definition of the PRT mandate included a function for 'reach-back ability' - the authority to bring in coalition forces in the event of threats to public order-but was subsequently dropped (Bishop 2004, p. 123). PRTs did little to provide security to Afghans: 'at best, a crude peace enforcement mechanism, capable of preventing severe backsliding but lacking the resources and stature to make serious improvements in security' (Thier 2006, p. 553). The modus operandi was typically for small units of international troops to respond - rather than preempt - security incidents i.e. 'security by reaction' as opposed to providing security as an explicit objective.

The development and launch of the PRTs occurred in a certain sequence of events, one which clearly mirrored the political environment in Afghanistan. The development of the PRT concept followed a request for rapid ISAF expansion by the Afghan President. The launch of the PRT plan coincided with the diversion of international attention and resources to Iraq. The initial deployment of PRTs was linked to the Coalition's simultaneous announcement of a shift from combat to reconstruction mode, where it described ongoing fighting that was unrelated to al-Qaeda and the Taliban as 'internal to the country' (Foxley 2007; Stapleton 2003b, p. 4; Hess 2003).

To their detractors, the PRTs represented an attempt to provide the 'ISAF effect on the cheap' and 'second-best to a straightforward extension of ISAF (McHugh and Gostelow 2004, p. 47; Stapleton 2007, p. 13). Amid the deteriorating security situation and reluctance to expand ISAF, the PRTs promoted an appearance of progress. US 
Defence Secretary Donald Rumsfeld described PRTs as 'the best thing that can be done to ultimately provide security' (cited in Hess 2003). At one point, Western policymakers spoke about 'soldiers on the ground all over Afghanistan' when roughly 400 were operational, as well as how PRTs were not only securing but building the country when PRT spending represented at most some $3 \%$ of total funding to the country. The PRTs also placated Western publics that undue financial resources and lives of troops were not being risked, as would have been the case with a large peacekeeping force (ACBAR 2002; O'Brien 2003, 2005, p. 214; Stapleton 2007, p. 2). The deployment of troops to Afghanistan represented the lowest per capita commitment of peacekeeping personnel to any post-conflict environment since the end of World War II. ${ }^{25}$. In summary, the PRTs allowed for a lighter footprint and substituted for higher levels of financial and troop commitment.

\section{Part 4: An Alibi/Substitution (The 'Security Dividend')}

When US Civil Affairs Teams were first deployed to Afghanistan and began to engage in civic action projects, some humanitarian organisations expressed concern that involving the military in assistance provision would distract it from its security mission (Gordon 2004). But the crux of the substitution was more subtle than a simple diversion of attention, resting with the PRTs and the notion of a 'security dividend'.

The assumption behind the PRTs was that by providing the stability of an armed presence and an environment for reconstruction and development, this would counter anti-government spoilers, expand the central government's authority and produce a 'security dividend'. Instead of confronting power relations with a credible military force, local power-holders were to be negotiated with and persuaded to 'come inside the tent' (Stapleton 2003a, p. 12; 2007, p. 46). The PRT manual declared the PRTs 'able to stabilise [unstable and insecure] areas because of the combined capabilities of its diplomacy, military and economic components' (ISAF 2012, p. 28). ${ }^{26}$

The notion of a security dividend produced by reconstruction and development went largely unquestioned by policymakers in the early years of international engagement (Stapleton and Keating 2016, p. 16), with one

\footnotetext{
${ }^{25}$ For the first three years of international engagement in Afghanistan, the ratio of soldiers to inhabitants was 1:1000, rising only to 1:2000 four years later. By comparison, the ratio in the post-war international military deployments to Bosnia-Hercegovina and Kosovo were 1:48 and 1:58, respectively (Johnson and Mason 2007, pp.84-5).

${ }^{26}$ The key premise underlying the conduct of the War on Terror is a holistic approach merging political and military action with a third toolkit of aid, reconstruction and development, referred to more commonly as the "Three-block War" or 3D approach (Aaronson 2007).
}

aspect overlooked in particular. Stabilisation supported by reconstruction and development activities is not synonymous with reconstruction or development, which requires a secure or uncontested environment (Aaronson 2009, p. 113). One of many studies into the impact of aid in Afghanistan concluded that 'it is not aid that causes security, but security that attracts aid' (Zurcher 2012; Zurcher et al. 2015, p. 103). Aid-based activities cannot by themselves produce a secure or uncontested environment.

The security dividend was by no means the only example of aid substituting for a long-term political strategy for Afghanistan's future. With no clear notion of what the desired 'end state' in Afghanistan was, and in the absence of any guidance from Washington, decisions were often made by US infantry or Special Forces units. Public donors (e.g. USAID) resorted to quick impact projects as a way of hedging their bets in this void (Chayes 2007, pp. 151-2) and also as a means to deliver a 'peace dividend' (Lockhart 2011, p. 272). The reliance on aid in the absence of a political strategy continued, even as the insurgency emerged. At one point, the International Crisis Group noted that when fighting insurgents, international military forces were placing increasing emphasis placed on development, or building things-preferably quickly-but the political component is missing' (International Crisis Group 2006, p. 14). Save the Children-UK Director-General Michael Aaronson drew parallels with the 1990s: 'we do not have the contextual understanding to plan and execute such interventions properly, and as a result we make massive mistakes. We believe we can use humanitarian or development assistance to help us achieve our objectives, but in reality we are back to... [relying] on humanitarian action as a substitute for effective political action' (2007, p. 4).

\section{Part 5: Substitution of Responsibility}

The emphasis placed by Western governments' on 'assisting' rather than peacekeeping later gave way to portrayals of the UK military deployment in Helmand in terms of reconstruction and development. The British Home Secretary stated that 'we're [there] to help and protect the Afghan people to reconstruct their economy and democracy. We would be perfectly happy to leave in three years' time without firing one shot' (C4 2009). From the initial hearts and minds operations by the US Civil Affairs teams to the reconstruction activities of the PRTs, the narrative coming from Western capitals sought to avoid military force and occupation and endow the international military presence with an image akin to community police or peacekeepers (Egnell 2010, p. 295; Piiparinen 2007, p. 154). The transformation of ISAF's role from peacekeeping to counter-insurgency 
went unacknowledged for some time as the hearts and minds' discourse continued. ${ }^{27}$ This discourse provided a feel-good storyline and concealed the failure of the counter-insurgency from Western publics (Goodhand 2013, p. 295; Foley 2008, p. 116).

Aid worker Nicholas Stockton wrote back in 2002 that 'an international assistance strategy...bereft of key strategic instruments' would not only serve as a political alibi but would also 'enable the burden of responsibility to be shifted to the assistance agencies....Strategic coordination when undertaken exclusively by assistance providers carries with it the risk of being used as a strategic scapegoat' (2002, pp. 33-4). Not quite as predicted, scapegoating materialised as follows. The international aid sector found itself lambasted, on more than one occasion, by parts of the national media for failing to consolidate military gains and even endangering the lives of British troops (Cohen 2007; Evening Standard 2007). Confusion of this sort results in the extraordinary situation where governmental and military actors are able to portray military success as 'humanitarian' and to blame military failure upon humanitarians. ${ }^{28}$ Scapegoating of this sort is possible once the respective roles of military and humanitarian actors have become blurred and the myth of a humanitarian or otherwise aid-based solution is accepted in the eyes of the general public.

\section{Other UN peacekeeping missions}

UN peacekeeping forces today are often authorised to deliver aid, including quick-impact projects, healthcare, water and food to win the trust of local populations (Hofman 2014). Some UN peacekeeping missions have exhibited behaviour that is reminiscent of the substitution process where involvement in assistance activities, either supporting agencies or delivering assistance directly, comes at the expense of protecting civilians.

The United Nations Mission in Sudan (UNMIS) was mandated to support the implementation of the Comprehensive Peace Agreement by providing force protection to military observers instructed with monitoring adherence to the terms of the peace agreement. The mission had a limited role in proactively protecting civilians. Instead, it verified the safety of roads for UN agencies and provided direct assistance such as building orphanages. When interviewed, UNMIS officials saw these assistance activities as a good use of the ample peacekeeping budget: 'with a Chapter 6 mandate, there is nothing for them to do, but it's costing \$1 billion a year so why not use them for development work?'. Another

\footnotetext{
${ }^{27}$ Most of the members of the international military coalition defined their role in a "non-kinetic" way (Aaronson 2009, p. 111).

${ }^{28}$ I cannot take ownership for this analogy, which belongs to former MSF head of mission in Afghanistan Michiel Hofman to whom I am grateful, interviewed February 2015.
}

UN interviewee explained the focus on humanitarian activities by the fact that the military observers did not require much force protection (Mowjee 2006, pp. 21-3).

The United Nations-African Union Mission in Darfur (UNAMID) has gone further in viewing aid delivery as part of its remit and justifying its presence in humanitarian terms, even when not providing effective civilian protection (Foley 2017, ch.7). Echoes of the 'security dividend' can be heard in some UN reports: '[t]he Mission facilitates the delivery of humanitarian assistance by aid agencies by providing escorts and logistical support, contributing to an area security...The Mission...is making much-needed contributions to the protection of civilians, facilitating the delivery of humanitarian assistance' (UN 2014, pp. 4, 14; 2015, p. 6; 2017, p. 7).

\section{South Sudan}

\section{Part 1: An Alibi/Substitution ('The Peace Dividend')}

In the last decade, heavy political investment took place to end the conflict between the north and south of Sudan, notably through the 2005 Comprehensive Peace Agreement which ended the conflict and paved the way for the independence of South Sudan. The level of US spending on humanitarian, development, reconstruction, security sector and peacekeeping support represented one of the largest US foreign aid investments in the following decade (Blanchard 2016, p. 17).

Following this agreement, the dominant paradigm informing international aid operations in the country was the theory of aid acting as a 'peace dividend': delivering services would abate the frequent outbreaks of violence due to local conflicts, so that peacefulness would be rewarded with aid. A multi-donor evaluation of aid to South Sudan poured cold water on the notion of a peace dividend. It found no 'direct causal link between the provision of basic services and the prevention or mitigation of violent conflict...which challenges the premise upon which a great deal of assistance to South Sudan rests', and noted their 'serious misgivings around the issue of a "peace dividend"' (Bennett et al. 2010, pp. 49, 131). The evaluation further concluded that the perception of unequal resources and services...is unlikely to be a reason in itself for violent conflict' and that the actual reasons for the conflict-ethnic division, land and cattle disputes and disaffected youth-are not typically influenced by aid (ibid, p. 94).

\section{Part 2: An Alibi/Substitution}

A report by the UN Secretary-General observed that 'preventing and ending conflicts and building peace is recognized in the United Nations Charter as our first and foremost responsibility to humanity. Yet, this effort is not where our political leadership or resources are presently focused... Often it seems to be easier for the 
international community to invest in humanitarian responses than in concerted efforts to prevent and resolve conflicts...political leadership is too often not only triggered by immediate narrowly defined national security and economic interests and only once a situation has deteriorated....it appears efforts to find political solutions have been suspended [in some conflicts]' (Ki-Moon 2016).

The conflict in South Sudan seems a case in point. Given the years of political investment to bring about peace and South Sudan's independence, a profound sense of disappointment and betrayal among foreign governments and international actors ensued following the outbreak of civil war in the newly independent state. The focus of donors and the UN largely fell back on raising funds for the UN-coordinated aid operation. In 2013 - the first year of the conflict-no single country in the world received more humanitarian funding than South Sudan (IASC 2014, p. 1).

At the same time, the US Administration sided with one of the war's belligerents President Salva Kiir, quietly acquiescing to the role of regional ally Uganda-itself one of the largest recipients of US security assistance-in sending arms to Kiir and in directly intervening militarily (Temin 2018, p. 19). The UN Panel of Experts on South Sudan identified the Kiir regime as 'the main belligerent in the war [which] continues to accord an aggressive military approach over a political solution to the conflict' (United Nations Panel of Experts on South Sudan 2017, p. 7). Only 5 years into the armed conflict did the UN Security Council agree to impose an embargo on the country. ${ }^{29}$ The UN Panel of Experts concluded that the supply of arms and ammunition was 'instrumental in prolonging and escalating the war... leading to large-scale violations of international humanitarian law' and noted that the purchase of three Mi-24 helicopters 'facilitated the expansion of the war and... emboldened those in the government...seeking a military solution to the conflict at the expense of the peace process' (United Nations Panel of Experts on South Sudan 2015, p. 3; 2016, p. 3).

The UN Mission in South Sudan (UNMISS) did not intervene when violence first erupted; they remained in their compounds but eventually succumbed to pressure from people fleeing to their gates in need of protection, resulting in ad-hoc 'protection of civilians' camps. UNMISS has been thinly spread and committed only to monitoring and providing a refuge for civilians sheltering on its baseswho account for less than $10 \%$ of the displaced and at risk population (p. 223; IDMC 2014, p. 5).

The doctrine of the integrated mission is the norm for $\mathrm{UN}$ involvement in conflict situations today: the UN combines its political, humanitarian and peacekeeping

${ }^{29} \mathrm{UN}$ Security Council Resolution 2428. components into one integrated mission. All of these are expected to work together under the leadership of the Humanitarian Coordinator $(\mathrm{HC})$ who is to take the lead in drawing together these various aspects of the response. In South Sudan, the HC was triple-hatted in the sense of also being the UN Resident Coordinator and the Deputy Special Representative of the Secretary General, giving authority in relation to UNMISS.

The account of an evaluator of the UN humanitarian operation in South Sudan in 2016 describes a lack of leadership from the UN-the UN leadership was based in-country and the UN headquarters in New York was not significantly involved-resulting in a tendency to focus on the humanitarian response than the wider issue of international effort to bring about peace. The $\mathrm{HC}$ was primarily concerned with raising humanitarian funds and only exchanged information with the political and military components of the UN, not drawing upon his considerable powers to bring together the military, political and humanitarian aspects of the UN response as part of a grand political strategy (Vaux 2017, p. 135).

Part 3: The Role of the International Humanitarian System International humanitarian agencies were unable to raise much money in direct appeals to general publics; attention was focused elsewhere and the war was difficult to explain in terms that would elicit public sympathy (Vaux 2017, p. 132). Consequently, the vast majority of donor funding passed through a gigantic UN relief operation. Aid funds were premised by donors on coordination with the UN; any agency receiving funds had to take part and comply with the UN coordination arrangements (ibid, pp. 29-30, 134). Any room for dissent was further limited by the logistical dependency of non-UN actors on the UN; with no major infrastructure in South Sudan, UN flights were the only way to travel. Incidents also occurred where the UN excluded journalists critical of the UN operation, bartering access for positive reporting. ${ }^{30}$

UN reforms in recent years have responded to a lack of leadership within the UN humanitarian response. The Humanitarian Emergency Response Review (HERR) observed that '[the UN's] performance has been very disappointing overall... [This] is true at a strategic level and an operational level... Too often cluster meetings are information sharing gatherings instead of the strategic decision-making forums they should be... There is rarely a vision beyond fundraising and rarely an organising narrative that draws together the disparate capacities... What is needed is a complete overhaul of strategic and operational leadership in the UN' (Ashdown et al. 2011,

\footnotetext{
${ }^{30}$ Comment from journalist and filmmaker Antony Lowenstein at The Centre for Investigative Journalism's Logan CIJ Talks Series, 'Disaster Capitalism: Q\&A', Goldsmiths, University of London, 12 April 2018.
} 
pp. 31-2). The Inter-Agency Standing Committee (IASC)'s Transformative Agenda for the global reform of humanitarian action in large-scale emergencies, agreed in 2011 , focuses on 'the effectiveness of our collective response through stronger leadership, more effective coordination structures... Humanitarian leadership will be strengthened... He or she will have "Empowered Leadership" to direct the overall response, with more authority over the planning, priority setting... and advocacy' (IASC n.d.).

The Transformative Agenda introduced Inter-Agency Humanitarian Evaluations (IAHEs) as part of the $\mathrm{Hu}-$ manitarian Programme Cycle. IAHEs aim to assess the extent to which the shared objectives of the Strategic Response Plan are met, as well as to contribute to learning from the collective response. The HERR had stated previously that 'what is necessary is to move away from a system where many agencies still continue to measure success in volume of food, goods or vaccines delivered rather than the impact on the affected population' (Ashdown et al. 2011, p. 40). Transformative Agenda documentation referred to the 'need to focus not on the process of implementing change but on the impact of change' (IASC n.d.).

The 2015 Inter-Agency Humanitarian Evaluation (IAHE) of the Level 3 Response to the Crisis in South Sudan was commissioned by the UN Office for the Coordination of Humanitarian Affairs (OCHA) and tested the humanitarian community's response to a 'systemswide' emergency and the UN system's leadership of the response under the Transformative Agenda. The purpose of the IAHE-as stated in the Terms of Reference-was to assess the extent to the inter-agency response met the objectives to respond to humanitarian needs set out in its strategic plans ${ }^{31}$ and whether these objectives were appropriate and relevant, as well as to capture lessons learned so as to enable collective learning from the humanitarian response, including the role of the UN mission (IASC 2014). The Terms of Reference added that 'the evaluation will be global in scope, in that it will cover all sectors of the emergency response to [the] conflict' (IASC 2014).

The first draft of the evaluation report contained a number of recommendations for a greater focus on peace: 'ultimately the situation cannot be resolved by any means other than a peace agreement. Although this may

\footnotetext{
${ }^{31}$ Four strategic objectives were agreed: 1 ) provide a coordinated lifesaving response to immediate humanitarian needs of conflict-affected people 2) provide protection to conflict-affected communities and ensure access to services 3 ) support the resumption of livelihoods activities by affected communities as quickly as possible and building resilience by providing integrated livelihoods assistance 4) provide logistical support, including transport of personnel and goods, accommodation for aid workers and storage of assets in deep field locations to enable the humanitarian response.
}

seem beyond the scope of humanitarian aid (and perhaps this IAHE) there are really no humanitarian, developmental or even military solutions without a much greater level of peace than exists today. This has been acknowledged in [strategic plans], and donors are individually active, but there has not been sufficient concerted and vigorous action... [and] up to now no particular action has been attached to it...The regional process has failed and greater international engagement is needed; potentially this case falls under the UN's Responsibility to Protect $(R 2 P)^{\prime}$. It also contained appeals to the Humanitarian Coordinator ( $\mathrm{HC})$ and Humanitarian Country Team (HCT): 'the HCT is chaired by the HC who is "tripled-hatted" in the sense of also being the UN Resident Coordinator and Deputy Special Representative of the Secretary-General (which gives authority in relation to UNMISS)...Donors have indicated that they welcome a broader approach in which resilience and longterm thinking are integrated into humanitarian action. In this the "three-hatted" HC is well placed (with authority in relation to humanitarian aid, development and UNMISS)...The challenge to the humanitarian system $(H C / H T)$ is to connect with other elements that will be needed to shape a comprehensive response to the crisis... Greater efforts must be made in... [the] direction [of peace] by humanitarian actors with strong leadership from the HC/HCT (Vaux 2015).

Following objections from the HCT and OCHA that the evaluation was surpassing its legitimate remit (Vaux 2017 , p. 135), the evaluation report was re-written with much of the original recommendations watered down or removed altogether, in particular the role of the HCT in forging a comprehensive response to the crisis. Notably, the significance of international actors, including the $\mathrm{HC} / \mathrm{HCT}$, in finding ways to support peace processes and raising the issue of $\mathrm{R} 2 \mathrm{P}$ in international circles was downgraded from 'critical' to 'important' (UNOCHA 2015). This was despite one of the UN officials having made a public call for a 'meaningful peace' a year prior (cited in EURACTIV 2014).

\section{Yemen}

\section{Part 1: An Alibi/Substitution}

A recent humanitarian report noted that 'children suffering in conflict today are not primarily suffering from a deficit of identified rights. Rather, they are suffering from a crisis of compliance with those rights. Armed actors... are committing violations against children. And they are often being met by...international indifference and...complicity...States and other armed actors are failing to uphold standards in conflict, both in their own conduct as military actors and in the behaviour they demand from others' (Save the Children 2019, pp. 10, 29). 
One of these conflicts is Yemen, where the Saudi-led coalition has progressively engaged in targeting civilian infrastructure (inc. hospitals and schools) and economic infrastructure (inc. food production and distribution) (Mundy 2017). The Saudi-led coalition has been enforcing a de-facto commercial blockade ${ }^{32}$ on sea and air routes into the country as well as placing restrictions on relief supplies, contributing to a famine which has claimed the lives of up to 85,000 civilians (McKernan 2018). At the same time, half the money donated to fund the 2018 UN appeal for humanitarian aid for Yemen came from Saudi Arabia and the United Arab Emirates, who are the largest contributors to the UN's funding plan, followed by the USA, UK and Kuwait.

Western governments have supported the Saudi-led coalition militarily, through the sale of weapons and also personnel and training, even providing direct supervision over bombing raids and specific guidance on bombing targets. The ICRC has made a private determination as to whether the UK government constitutes a party to the conflict (see Merat 2019). Some telling exchanges have taken place in the British Parliament, which demonstrate how a resort to the humanitarian imperative can relieve pressure and thus substitute for a more fundamental change in foreign policy. When asked about the British government's military involvement in the war in Yemen and called upon to halt arms sales, then Prime Minister Theresa May gave the following replies:

These issues are being investigated...and we have taken action. He's right to refer to the humanitarian crisis in the Yemen and this country is one of those that is in the forefront of ensuring that humanitarian aid is provided. That is a record of which I believe this country and this government can be proud around the world in terms of the actions that have been $\operatorname{taken}^{33}$

We are all concerned about the appalling humanitarian situation in Yemen and the effect that it is having on people, particularly women and children. That is why the Government have increased our funding for Yemen.... We are the third largest humanitarian donor to Yemen. We are delivering lifesaving aid... I was pleased that when I went to Saudi Arabia in December I met the Crown Prince, and raised with him the need to open the port of

\footnotetext{
${ }^{32}$ This blockade has consisted of a set of restrictions, inspections and other measures of interference, which have caused such extensive delays that the prices for basic household commodities escalated massively and become unaffordable.

${ }^{33}$ This exchange is available in video format at: https://www.youtube. com/watch?v=hrMLXuRzZKU.
}

Hodeidah to humanitarian and commercial supplies. I am pleased to say that Saudi Arabia then did just that ${ }^{34}$

Part 2: The Role of the International Humanitarian System The charge placed against Western-based international humanitarian NGOs is that they have presented a decontextualized view of the conflict in Yemen that is devoid of the underlying political causes of and culpability for the violence. One example is a short film appeal by Save the Children titled 'Censored'. ${ }^{35}$ It portrays the horror of aerial bombing as experienced by young children, but in an unspecified Middle Eastern country and also neglects to mention the actor responsible for the bombing. Humanitarian appeals such as this seek to engage the general public only through soliciting donations to the international aid effort, rather than as informed citizens attempting to influence foreign policy to tackle the causes of suffering.

Humanitarian NGOs have exhibited clear tension between justifying a humanitarian programme and raising public awareness of one clear cause of humanitarian suffering: the transfer of arms. Where humanitarian NGOs have highlighted arms sales and called for a suspension, it has been accompanied by praise for the financial contribution made by their national government to the international aid effort: 'British aid is saving lives, but British arms may be contributing to the growing number of civilian deaths...Britain should be proud of the $155 \mathrm{~m}$ it has already given to Yemen to meet its growing humanitarian needs. It should, however, suspend arms supplies to any party engaged in the conflict' (Oxfam 2015). By contrast, The Guardian newspaper directly challenged the contradiction between simultaneously sending arms and aid: 'The UK, which has licensed $£ 3.3 \mathrm{bn}$ worth of arms sales since the Yemen conflict began, boasts of increasing aid by $137 \mathrm{~m}$. The pledge would be laughable if it were not so shameful...No sum can restore lost limbs or revive the dead' (The Guardian 2016).

\section{Closing observations, conclusions and avenues for future research}

The constancy of the humanitarian alibi?

In the early 2000s, Fiona Terry wrote of 'the emergence of a new normative paradigm...in which humanitarian action becomes an alibi for politicians driven to "do something” by domestic constituencies' (2002, p. 194). This paper has presented a series of evidence to show

\footnotetext{
${ }^{34}$ United Kingdom of House of Commons Hansard, Volume 637, Column 299, debated on 7 March 2018. https://hansard.parliament.uk/ Commons/2018-03-07/debates/c938cbd7-16e5-4a90-9c59-44ed80cc2 ec0/CommonsChamber.

${ }^{35}$ The video is available to view here: https://www.academyfilms.com/ portfolio/save-the-children-censored.
} 
that this paradigm is alive and well. There is inevitably a risk of case selection bias in professing the 'constancy of the humanitarian alibi', that is, a constant process of substitution throughout history. But it is likely that the substitutionary phenomena identified in this paper have been present in other conflicts, for the simple reason that there is almost always something more that could be done, if only in theory. Humanitarian actors that view their role as watchdogs of the vulnerable will always push for governments to go beyond providing humanitarian relief and will judge anything less as insufficient. The humanitarian alibi critique is normative in that it reflects the outlook of the observer as to what that action should actually consist of, and it also presupposes that successful international intervention is possible in each and every context. In a sense, the humanitarian alibi exists in the eye of the beholder.

But, as many aid workers would privately concede, 'the only response to the suffering of a conflict that would really make a difference is resolute action to address its causes... [W] hether humanitarian organisations and others champion it or not, there is no prospect of action in the great majority of conflict situations' (Morris 2003, p. 206; see also Brauman 1995, p. 88). If, for the most part, there is no prospect of action beyond humanitarian aid intervention, a better benchmark is needed to measure the humanitarian alibi than an absolutist notion of substitution. The fact that governments and multilateral donors take credit for aid interventions in the place of more powerful mechanisms to resolve the conflict and save lives does not mean those mechanisms would necessarily materialise if the aid option was somehow made unavailable (Byrans et al. 1999, p. 14). Determining preemption (of an international intervention to resolve a conflict) with any certainty is fraught with difficulty, relying on counterfactuals as it does. Thus, the international humanitarian response may not actually preempt an international political intervention from occurring; it may simply off-set public pressure for such an intervention.

\section{The humanitarian alibi: redefinition required}

Inaction constitutes a decision not to act. As such, it is a form of action. In this regard, the phrase 'a failure of political will' means nothing: 'it is political will-if such a thing exists empirically - to choose to do something different for other reasons, the cost-benefit ratio coming out against action' (Hopgood 2015). Likewise, disengagement is not an abandonment of politics; it is a type of politics. The nature of disengagement is such that it is 'not old fashioned isolationism... [It] is selective, purposeful and varies among issues and parts of the globe' (Hehir 1998, p. 38).
It is rare for political powers to be disinterested in a conflict to the point of lacking a preferred outcome on the battlefield. There is a spectrum of interaction, ranging from 'abstention' (refraining from intervening or becoming involved in a marginal way) to 'involvement' (engagement benefits one camp and disadvantages the other(s) but stops short of offering military intervention to the favoured party) to 'intervention' (bringing the conflict to a rapid conclusion by a concerned military campaign against one of the warring parties) (Bradol 2004, pp. 10-20). Any of these modes of interaction can co-exist with an international humanitarian response. One aid worker puts it, 'in the absence of foreign policy, humanitarian [aid] intervention replaces it...This allows for political intervention by proxy' (p. 22). Where governments have invested in an international humanitarian response to a violent conflict, they have not failed to agree upon a political solution. Rather, the political solution is to use humanitarianism to contain the crisis situation as an alternative solution emerges, for example when a certain level of war-weariness among the belligerents is reached and/or when the balance of power on the battlefield is conducive to external military intervention on behalf of one armed faction.

Where international humanitarianism is being instrumentalized more directly to achieve political objectives (e.g. militarisation of aid, invocation of humanitarian justifications for warfare, UN 'integrated' approaches to political and humanitarian action), these political objectives will not necessarily be that of protecting the civilian populations and resolving the conflict in question. As such, integrated political-humanitarian approaches are no panacea to the substitutionary effect of humanitarianism and are not by themselves effective at generating the desired political engagement. The 'coherence' agenda is another case in point. Not only has it failed to end the disengagement by national governments from ongoing crises, it has actually enabled this disengagement: 'the revitalisation of aid in conflict management has coincided with a period of withdrawal of conventional political engagement in many areas of the least developed countries...As the differences between aid and politics are made to disappear, there is an effective withdrawal of those bodies with a conventional political mandate...Aid becomes the primary form of political engagement, but is confined in its mission largely to conventional instrumentation' (Leader and Macrae 2001, p. 295). As aid bodies become primarily responsible for international policy in some contexts, political investment can then be redirected to other contexts of greater geopolitical importance.

The focus of the academic literature is imbalanced, with greater emphasis placed on the politicisation of aid (e.g. by Western powers in contexts such as 
Afghanistan) at the expense of the role of coherence in fostering disengagement (DuBois 2018, p. 15). This paper has sought to make a helpful corrective to this imbalance, detailing the substitutionary effect of aid even where it is being made to work to accomplish political objectives. Additional correctives are required to rectify this imbalance.

It should not be surprising that aid can be made to work to simultaneously evade political engagement and accomplish political objectives, when one recognises that evading political engagement is a political objective in itself. One should also recall the limited effectiveness of aid in engineering political outcomes. Aid has shown little leverage or capacity to steer domestic political processes in different directions, with a penchant for producing distorted and partial results (Uvin 1993; Uvin and Biagiotti 1996). A general rule is that aid for aid to work, the political circumstances must be conducive to it doing so (Vaux 2017, pp. 76, 92; Riddell 2007). All this underlines the necessity of political, not primarily aidbased, intervention. As the JEEAR noted, 'humanitarian action cannot serve as a substitute for political, diplomatic and, where necessary, military action. The onus of responsibility must...be upon the political and diplomatic domain to address...emergencies' (Borton et al. 1996, pp. 191-2).

A wider range of interactions between states and conflict-related crises must be taken into perspective, that is, both the systemic neglect of crises and the systemic harm that exacerbates and perpetuates these crises. It is not only a failure to take political action that allows conflict and suffering to fester; forms of political action fuel conflict and exacerbate suffering. In this respect, the term 'political failure' is far too kind. It is only a failure in the vague sense of a collective failure by humanity.

Some care is needed not to underestimate the dilemmas involved in securing the right incentives and discentives for peacemaking. The humanitarian alibi critique is guilty of simplification when it overlooks these difficulties. This includes decisions on whether to reward or punish particular armed factions, how forcefully to push ahead with political and social reforms, and whether to impose economic sanctions and an arms embargo. Intervening governments and donors may genuinely feel that they have to choose between a neglectful hands-off approach and a neo-colonial hands-on approach, with a sense of 'damned if you do, damned if you don't' (Keen 2009a, pp. 28-9). Even restricting the supply of arms into conflicts is not clear-cut, as it may in some cases increase civilians' vulnerability to violence (e.g. Bosnia-Hercegovina). Substantive investment in a country can quite easily collapse and fail to deliver the promised gains of peace and stability (e.g. Rwanda,
South Sudan). The claim that supporting one armed faction politically and militarily is necessary to force restraint, reduce the violence and resolve the conflict (most notably made by Western governments regarding Yemen $^{36}$ ) must be carefully considered ${ }^{37}$ no matter how dubious they may be.

A helpful yardstick is where the geopolitical and economic interests of states begin to trample on the rights and needs of conflict-affected populations: 'in the end, it is the people...that fall victim to the politically expedient policies of powerful states' (Terry 2002, p. 214). When forming diplomatic alliances, governments rarely make the treatment of civilian populations an overriding concern: 'there are still many friends whose sins are being ignored or quickly forgotten' (Keen 2009b, p. 3).

Conflict analysis shows the presence of 'grievance' and 'greed' elements. Greed includes elite interests which exploit and deprive people: 'this is valid at all different levels right up to civil wars...or even the geopolitical competition that has caused disaster...these greed elements will very often be found to have links to the establishment of aid-giving countries' (Vaux 2017, pp. 183-4). The most vivid example of greed is the sales of arms. The five permanent UN Security Council members, charged with primary responsibility for preserving global peace and security, are responsible for almost three-quarters of global arms sales: ${ }^{38}$ 'retailing peace while wholesaling arms' (cited in Deen 2019). No less impactfully, the same forces of international capitalism which provide weaponry also create the economic incentives for local actors to pursue warfare over commercially valuable natural resources: 'greed has a trail that leads beyond the war-torn society to global companies and consumers alike' (Keen 1999, p. 87; Slim 2004, p. 167). International demands for economic liberalisation, austerity and the dismantling of state institutions (e.g. from International Monetary Fund/World Bank privatisation and structural adjustment programmes) as well as uneven development and inequitable growth have all fuelled violent conflict (see Keen 1996, pp. 16-7; 1997, pp. 73-4; 2000a; 2000b, pp. 28-9, 39-40; 2005; Stewart 2008).

[Crisis] situations...do not happen overnight. They invariably follow from a history of culpable negligence or equally culpable complicity by the

\footnotetext{
${ }^{36}$ In an opinion peace published online, then British Foreign Secretary Jeremy Hunt (2019) argued that the pursuit of peace in Yemen required that the government continue selling weapons to one of the combatants, adding that it would be 'morally bankrupt' to halt military exports to the Saudi-led coalition.

${ }^{37}$ For example, the presence of American and particularly French armies on the ground somewhat diminished the capacity of the rump of the former Rwandese regime to use the camps as a staging ground for its rehabilitation. Once these armies had departed, this process got well underway (Jones 1997, p.39).

${ }^{38}$ SIPRI Arms Transfer Database, 11 March 2019.
} 
international community (de Waal and Omaar 1993, p. 57)

"Interventions" are not simply something that "the West" or "the international community" does to remedy humanitarian disasters once they occur; more often than not, interventions occur prior to the disaster, perhaps helping to precipitate it (Keen 2000c, p. 19)

The typical way in which states go about conducting their affairs and dealing with political issues gives rise to secondary problems and consequent suffering. There is great utility in having the international humanitarian system available to play the role of 'clean-up' and to tend to the suffering, in much the same way that humanitarian aid intervention performs a 'clean-up' role on the battlefield and lessens the costs of war for belligerents. ${ }^{39}$ By necessity, it maintains the status quo and precludes a change in state behaviour.

Major powers will always need some means to legitimate rule and excuse failure at the global level, and...some form of care for the casualties of the wider social order will be necessary... [International humanitarianism] allows the deeper reasons for inequities of power and money to go unchallenged [and] it performs the role of alibi for the political actors whose foreign policy choices lie behind many of our major international crises (Hopgood 2019, pp. 10-11).

Huge amounts of aid money are needed to patch up the follies of Western dabbling (Vaux 2017, p. 2)

The implications here are profound, and necessarily force a re-definition of the humanitarian alibi phenomenon. Traditional understandings of the humanitarian alibi have centred on systemic neglect. This focus, which comes at the expense of considering systemic harm, will no longer do. A expanded concept of the humanitarian alibi must encompass the substitution associated with systemic neglect (assisting victims of harm rather than protecting from harm) and the

\footnotetext{
${ }^{39}$ An interesting side-note here is that the founder of modern nursing Florence Nightingale presciently opposed the first creation of the international humanitarian system, the ICRC: 'Miss Nightingale...entertains no doubt with regard to Mr [Henri] Dunant's proposal. She says it is objectional because...such a Society would take upon itself duties which ought to be performed by the Government of each country and so would relieve them of responsibilities which really belong to them and being relieved of would make war more easy' (cited in Moorehead 1998, p. 30; see also Hutchinson 1996, pp.349-50).
}

substitution associated with systemic harm (assisting rather than avoiding harming).

A third type of substitution exists, one which also reflects the reluctance to consider harm. In this substitution, a focus on protecting from harm eclipses the importance of avoiding harming. In the zeal to remedy conflict-related crises and in particular to prevent mass atrocity crimes, supporters of international military intervention assume far too readily that crisis situations are the result of sins of omission rather than sins of our commission. The political and economic interventions by states that cause, exacerbate and perpetuate violent conflict are overlooked; only greater interventionism is how to respond. Far greater systemic harm, such as that caused by structural violence and extreme poverty, is disregarded. In practice, international military intervention responds only to 'spikes' in violence and suffering, that is, outbreaks of violent conflict or incidences of atrocity crimes. These periodic episodes of international military intervention very much serve the interests of the status quo: 'what frightens observers is the idea of uncontrolled, ongoing, unpredictable suffering... [intervention] create[s] a moment of "new normal" where the flow has been stemmed, the hole plugged' (Hopgood 2019, p. 11). This substitution form is beyond the scope of this paper but merits investigating and exposing further.

\section{The role and responsibility of the international humanitarian system}

Once the roles of governmental, military and humanitarian actors have been blurred in the minds of the public, the effect is to alter perceptions of responsibility. Specifically, it shifts the onus for resolving the conflict and protecting civilians away from governmental and military actors and towards humanitarian actors (e.g. Bosnia-Hercegovina, Afghanistan). This diversion of responsibility is an intrinsic part of the substitution process, as is the use of humanitarian framing to describe the political problems of war and violent conflict.

MSF-USA General Director Joelle Tanguy blamed the use of humanitarian reasons to justify military intervention for 'develop $[i n g]$ the fallacious impression that forceful and well-planned humanitarian action can stop a war [or] resolve a conflict' (2000, p. 9). But humanitarian actors play a key role in the framing of crisis situations as 'humanitarian': 'framing an issue as a distinctly humanitarian one limits the responses available...We instinctively know that the way we frame issues leads naturally to particular types of solution' (Scott-Smith 2016, pp. 19-20). Treating conflict within this framework has a profound impact in framing the public 
debate in donor countries: 'the force of the humanitarian alibi lies in its public shaping of the debate' (DuBois 2018 , p. 6). The function of this operating mode is clear:

You can't confuse the public with complex issues. Starving babies and droughts are something that people can understand (Giradet 1993, p. 46)

The true remedies of active political engagement, decisive diplomatic dialogue, and even forceful military intervention are undermined by the appeals for compassion and generosity. Images of suffering, haunting stories, and "flies in the eyes" photography are intended to evoke pity, not outrage (Martone 2006, p. 4)

The very presence of relief operations is evidence of a political failure to have prevented and resolved conflict. By highlighting the reality of their work, humanitarians hope to achieve political recognition of the problem (de Torrente 2005, p. 238; ICRC 2000, pp. 45-6, 328). This produces a tension. By forcefully highlighting their work, they risk giving the fallacious impression that a crisis is being satisfactorily addressed. Aid agencies are naturally inclined to highlight and even exaggerate their own successes, however limited in the grand scheme of things. At one point, one aid commentator accused traditional humanitarian culture of having led 'Western governments and donating publics...into believing the fairy tale that their aid can solve profound political problems, when it cannot... [The] minimum duty of the humanitarian is therefore to tell the truth...Humanitarians must never hint otherwise, not allow the existence or actions be used to imply otherwise' (de Waal 1997, p. 221). Thus, humanitarian actors must constantly remind governments and the public that, without political action, very little will be achieved. In particular, they must not give donors the idea that with sufficient funding they are doing anything significant. ${ }^{40}$ As this sits at odds with the humanitarian and financial imperatives of intervening agencies, the tension becomes palpable. In the words of a former aid worker, 'resolutions to problems are not in the interests of aid agencies that are generating hundreds of millions of dollars a year'. ${ }^{41}$

\footnotetext{
${ }^{40}$ Interview with Tony Vaux, former aid worker, June 2018.

${ }^{41}$ Interview with John Fawcett, former International Rescue Committee Country Director, March 2015.
}

Another position that humanitarian actors could adopt is to highlight the substitution of protection for assistance, not the politicisation and militarisation of humanitarianism (that is, the use of humanitarian rationales by governments to justify intervention or the involvement of military forces in delivering assistance). Aid agencies hardly stand on solid ground when they engage in turf wars with political and military actors and when they prioritise the autonomy of their own sector. They do far better when they highlight precisely the way in which these actors are failing to meet the needs of civilian populations for protection and security.

The introduction to one book on humanitarian action describes the awareness that humanitarian action can used to exclusively treat the symptoms of violent conflict as a 'humbling but essential realisation for those who accept leadership positions in the field' (Cahill 2007, p. 3). Marc DuBois remarks that 'the problem of the humanitarian alibi...is one that the humanitarian sector only half recognises'. He ponders over whether aid workers truly 'understand the reality behind the alibi' (2018, p. 6).

Fiona Terry writes that 'aid organisations do not inherit the responsibilities that others have failed to meet, but is it enough for them to decry the "humanitarian alibi"? .... Rather than accepting the instrumentalization of humanitarian action... humanitarian actors need to reclaim an activist role, reminding states that failure to meet their responsibilities is what allows crises to unfold in the first place' (2002, pp. 207, 217). Armed with an expansive understanding of the humanitarian alibi, this activist role must resist any collusion in systemic neglect and harm. ${ }^{42}$ African Rights once pointed out that 'most humanitarians chose their career because they believe they can make a difference to poor and suffering people. If they find that the obstacles to making a difference are found "at home" in the West, they should not neglect changing attitudes there too' (de Waal and Omaar 1995, p. 52). Tony Vaux adds that 'this inconvenient truth...has huge implications; instead of aid programmes we need global politics and democracy that holds powerful governments to account' (2017, p. 184). Humanitarian actors face a choice between the low road of remaining alibis or the high road of becoming activists.

\footnotetext{
${ }^{42}$ Further research could delve into this humanitarian 'activist role'. It might designate the various components and stages of the humanitarian activist toolkit, e.g. public stances, political positioning, humanitarian withdrawal, etc.
} 


\section{Abbreviations}

HC: Humanitarian coordinator; HCT: Humanitarian country team; IAHE: InterAgency Humanitarian Evaluation; IASC: Inter-Agency Standing Committee; ICRC: International Committee of the Red Cross; ICG: International crisis group; ISAF: International Security Assistance Force; JEEAR: Joint Evaluation of Emergency Assistance to Rwanda; KFOR: Kosovo Force; MSF: Médecins sans Frontières; NGO: Non-governmental organisation; NATO: North Atlantic Treaty Organisation; OSCE: Organisation for Security and Cooperation in Europe; OCHA: United Nations Office for the Coordination of Humanitarian Assistance; UNHCR: Office of the United Nations High Commissioner for Refugees; OSCE: Organisation for Security and Cooperation in Europe; PRTs: Provincial reconstruction teams; R2P: Responsibility to Protect; UK: United Kingdom; UN: United Nations; UNAMID: United Nations-African Union Mission in Darfur; UNAMIR: United Nations Assistance Mission in Rwanda; UNMIS: United Nations Mission in Sudan; UNMISS: United Nations Mission in South Sudan; UNMIK: United Nations International Administration Mission in Kosovo; UNPROFOR: United Nations Protection Force; US: United States

\section{Acknowledgements}

Not applicable.

\section{Author's contributions}

The sole author of this paper was responsible for the entire research and production process. The author(s) read and approved the final manuscript.

\section{Funding}

No external funding received.

\section{Availability of data and materials}

Secondary academic literature supplemented by interviews with individuals with experience of the cases of armed conflict examined. No quantitative datasets used.

\section{Declarations}

\section{Ethics approval and consent to participate}

Not applicable.

\section{Consent for publication}

Not applicable.

\section{Competing interests}

The author declares that he has no competing interests.

Received: 9 August 2019 Accepted: 31 August 2021

Published online: 12 November 2021

\section{References}

Aaronson M (2007) A holistic approach to the war on terror. Opinion. Available via UNIVERSITY OF SURREY. http://epubs.surrey.ac.uk/713935/3/Aaronson\%2 02007\%20A\%20holistic\%20approach\%20to\%20the\%20war\%20on\%20terror. pdf. Accessed 23 Apr 2017

Aaronson M (2009) International NGOs and international development assistance: what they can and cannot contribute to combating terrorism. In: Tsang S (ed) Combating Transnational Terrorism. Searching for a new paradigm. PSI Reports. Praeger, Praeger Security International/ABC-CLIO, Santa Barbara, pp $103-122$

ACBAR (2002) Policy brief: NGOs concerns and recommendations on civil-military relations. ACBAR, Kabul

ACBAR (2006) Aid effectiveness in Afghanistan: At a Crossroads. ACBAR, Kabul

Adelman H, Suhrke A (1996) The international response to conflict and genocide: lessons from the Rwanda experience. Study II: Early Warning and Conflict Management, Steering Committee of the Joint Evaluation of Emergency Assistance to Rwanda, London

African Union (2000) Rwanda: the preventable genocide. Available via REFWORLD. https://www.refworld.org/pdfid/4d1da8752.pdf. Accessed 19 July 2021

American Presidency (AP) Project (2002) Press briefing by Ari Fleischer, 25 February 2002. Available via AMERICAN PRESIDENCY PROJECT. http://www. presidency.ucsb.edu/ws/index.php?pid=61634. Accessed 23 Apr 2017
Andreas P (2008) Blue helmets and black markets: the business of survival in the siege of Sarajevo. Cornell University Press, London/thica

Annan K (1999) Report of the Secretary-General Pursuant to General Assembly Resolution 53/35: The Fall of Srebrenica. United Nations, Geneva

Anonymous (1998) Introduction: the humanitarian debate: content and context. Refugee Surv Q 17(1):vi-xvi. https://doi.org/10.1093/rsq/17.1.vi

Ashdown P, et al (2011) Humanitarian Emergency Response Review. Department for International Development, London

Associated Press (2002) U.N. Afghan Forces to Be Extended, 28 March 2002

Balanzino S (1999) NATO's humanitarian support to the victims of the Kosovo crisis. NATO Rev 47(2):9-13

Barakat S, Guistozzi A, Langton C, Murphy M, Sedra M, Strand A (2008) Department for international development. understanding Afghanistan-strategic conflict assessment - 2.4 Final Report. Post-war Reconstruction and Development Unit, York

Barnett M (1996) The politics of indifference. In: Cushman T, Mestrovic S (eds) This Time We Knew: Western Responses to Genocide in Bosnia. New York University Press, New York/London, pp 128-162

Barnett M (2002) Eyewitness to a genocide. Cornell University Press, Ithica

Bayart J-F, Massiah G (1995) La France au Rwanda: Entretien. Les Temps Modernes 583:217-227

Bellamy A (2003) Humanitarian responsibilities and interventionist claims in international society. Rev Int Stud 29(3):321-340. https://doi.org/10.1017/S02 60210503003218

Bennett J, Pantuliano S, Fenton W, Vaux T, Barnett C, Brusset E (2010) Aiding the peace: a multi-donor evaluation of support to conflict prevention and peacebuilding activities in Southern Sudan 2005-2010. ITAD Ltd, Hove

Binet L (2015) Medecins sans Frontieres and the War in Former Yugoslavia 19922003. MSF, Paris

Bishop J (2004) Relations with the military: the InterAction experience. In: UNOCHA (2004) The humanitarian decade: challenges for humanitarian assistance in the last decade and into the future. VOI II: Gen Ass Res 46/182: THe development of practice, principles and the humanitarian framework. UNOCHA, New York, pp 121-124

Blair T (1999) Crisis in Europe--the War Must Go on. Sunday Mirror, 9 May 1999

Blair T (2001) Memo to President George W Bush, dated 4 December 2001. Available via BBC. http://news.bbc.co.uk/2/shared/bsp/hi/pdfs/06_07_2016_ memo4dec01.pdf. Accessed 25 July 2018

Blanchard L (2016) Conflict in South Sudan and the Challenges Ahead. Congressional Research Service Report, Washington D.C

Blumi I (2005) Administration and Governance in Kosovo: lessons learned and lessons to be learned. Policy Research Series Occasional Paper, Kosovar Institute for Policy Research and Development, Pristina/Geneva

Borton J, Brusset E, Hallam A (1996) The International Response to Conflict and Genocide: Lessons from the Rwanda Experience. Study III: Humanitarian Aid and Effects, Steering Committee of the Joint Evaluation of Emergency Assistance to Rwanda, London

Borton J, Eriksson (2004) Lessons from Rwanda-lessons for today. assessment of the impact and influence of the joint evaluation of emergency assistance to Rwanda. Danish Ministry of Foreign Affairs, Evaluation Department, Aarhus

Boutros-Ghali B (1994a) Report of the Secretary-General on emergency assistance for the socio-economic rehabilitation of Rwanda A/49/516. United Nations, Geneva

Boutros-Ghali B (1994b) Report of the UN Secretary-General on Security in the Rwandese Refugee Camps S/1994/1308. United Nations, Geneva

Boutros-Ghali B (1999) Unvanquished: A US-UN Saga. Random House, New York

Boyle M (2010) Revenge and reprisal violence in Kosovo. Confl Secur Dev 10(2): 189-216. https://doi.org/10.1080/14678801003665968

Bradol J-H (2004) The sacrificial international order and humanitarian action. In: Weissman F (ed) In the Shadow of 'Just Wars': Violence, Politics and Humanitarian Action. Hurst and Company, London, pp 1-25

Brauman R (1995) Genocide in Rwanda: we can't say we didn't know. In: Queinnec E, Rigal J (eds) Populations In Danger. La Decouverte, Paris, pp 85-91

Brauman R (1996) Mortelles illusions: Bosnie, la guerre des intellectuels. Libération, 14 September 1996

Brauman R (2004) From philanthropy to humanitarianism: remarks and an interview. South Atlantic Q 103(2/3):397-417. https://doi.org/10.1215/00382 876-103-2-3-397

Bryer D (1996) Lessons from Bosnia: the role of NGOs. Seminar paper presented at All Souls College, Oxford University, 1 March 1996. (on file with the author)

Burkhalter H (1994/5) The question of genocide: the Clinton administration and Rwanda. World Policy J 11(4):44-54 
Byrans M, Jones B, Stein J (1999) Mean times: humanitarian action in complex political emergencies stark choices, cruel dilemmas. report of the NGOs in complex political emergencies program on conflict management and negotiation, University of Toronto

Byrnes S (2013) The Kosovo diplomatic observer missions. In: Pettifer J (ed) Albania and The Balkans: Essays in Honour of Sir Reginald Hibbert. Elbow Publishing, Cornwall, pp 217-242

Cahill K (2007) Introduction. In: Cahill K (ed) The pulse of humanitarian assistance. Fordham University Press \& Centre for International Cooperation, New York, pp 1-10

CARE International (2002) CARE International in Afghanistan Policy Brief: Rebuilding Afghanistan A Little Less Talk a Lot More Action

Carlsson I, Sung-Joo H, Kupolati RM (1999) Report of the independent inquiry into the actions of the United Nations during the 1994 Genocide in Rwanda S/1999/1257. United Nations, Geneva/New York

Channel 4 (2009) FactCheck: a shot in Afghanistan? Available via CHANNEL 4 http://www.channel4.com/news/articles/uk/factcheck+a+shot+in+afghanista n/3266362.html. Accessed 23 Apr 2017

Chayes S (2007) Punishment of Virtue: Inside Afghanistan after the Taliban. Portobello, London

Chipman J (1989) French power in Black Africa. Blackwell Publishers, Oxford

Christian Aid (2004) The politics of poverty: aid in the New Cold War. Christian Aid, London

Clinton B (1999) Address by Bill Clinton to the $54^{\text {th }}$ Session of the UN General Assembly. Available via US DEPARTMENT OF STATE. https://2009-2017.state. gov/p/io/potusunga/207554.htm. Accessed 23 Apr 2017

CNN (2001) Transcript: leaders react to taking of Kabul. Available via CNN. http:// edition.cnn.com/TRANSCRIPTS/0111/13/bn.01.html. Accessed 23 Apr 2017

CNN (2002) Bush, Karzai vow to rebuild Afghanistan, 28 January 2002

Cohen N (2007) Now we won't even let the Brave take Risks. The Guardian, 11 November 2007

Dachy E (2001) La Raison Humanitaire au Kosovo. Les Temps Modernes 615-6(4): 114-134. https://doi.org/10.3917/Itm.615.0114

Dachy E (2004) L'action humanitaire : realités et représentations. Les Temps Modernes 627(2):22-42. https://doi.org/10.3917/ltm.627.0022

de Saint-Exupery P (1998) Rwanda : Les Trous Noirs d'une Enquete. Le Figaro, 17 December 1998

de Torrente N (2005) MSF's relation to political power-strengthening our independence and building a renewed base of support for humanitarian action. In: My Sweet La Mancha - Voluntary and Invited Contributions, December 2005. Médecins sans Frontières (internal document)

de Waal A (1997) Famine Crimes. James Currey, Oxford

de Waal A, Omaar R (1993) Somalia operation restore hope: a preliminary assessment. African Rights, London

de Waal A, Omaar R (1994) Humanitarianism unbound: current dilemmas facing multi-mandate relief operations in political emergencies. African Rights, London

de Waal A, Omaar R (1995) Imposing empowerment: aid and civil institutions in Southern Sudan. African Rights, London

Deen T (2019) UN Security Council Members: Preaching World Peace by Day, Peddling Lethal Weapons by Night. Available via TOWARD FREEDOM. https:// towardfreedom.org/story/archives/middle-east/un-security-council-memberspreaching-world-peace-by-day-peddling-lethal-weapons-by-night/. Accessed 20 July 2021

Destexhe A (1993) L'Humanitaire impossible ou deux siecles d'ambiguite. Armand Colin, Paris

Destexhe A (1996) From Solferino to Sarajevo. Health Hum Rights 2(1):46-57. https://doi.org/10.2307/4065235

Destexhe A (2000) Neutrality or impartiality. In: Cahill K (ed) Preventative diplomacy: stopping wars before they start. Routledge, London, pp 101-118

Dietrich J (2005) The George W. Bush foreign policy reader: presidential speeches with commentary. M.E. Sharpe, London

Dobbins J (2008) After the Taliban: nation-building in Afghanistan. Potomac Books Inc, Dulles

Donini A (2009) Humanitarian Agenda 2015: principles, power and perceptions-Afghanistan: Humanitarianism under Threat. Feinstein International Centre, Medford

Donini A, Fast L, Hansen G, Harris S, Minear L, Mowjee T, Wilder A (2008) The state of the humanitarian enterprise. Humanitarian Agenda 2015: Final Report. Feinstein International Centre, Medford

DuBois M (2018) The new humanitarian basics. HPG Working Paper. Overseas Development Institute, London
Duffield M (1994) Complex political emergencies : with reference to Angola and Bosnia, an exploratory report for UNICEF. School of Public Policy, University of Birmingham, Birmingham

Dziedzic M (2006) Kosovo. In: Durch W (ed) Twenty-first-century peace operations. United States Institute for Peace \& The Henry L. Stimson Centre, Washington DC, pp 319-388

Economides S, Berdal M (2007) Kosovo. In: Economides S, Berdal M (eds) United Nations Interventionism, 1991-2004. Cambridge University Press, Cambridge, pp 217-245

Egnell R (2010) Winning 'hearts and minds'? A critical analysis of counterinsurgency operations in Afghanistan. Civil Wars 12(3):282-303. https://doi. org/10.1080/13698249.2010.509562

Eriksson J (1996) Synthesis report: the international response to conflict and genocide: lessons from the Rwanda experience, Steering Committee of the Joint Evaluation of Emergency Assistance to Rwanda, London

Erlanger S (2000) U.N. Official warns of losing the peace in Kosovo. New York Times, 3 July 2000

Euractiv (2014) Sue Lautze: South Sudan needs 'meaningful peace'. Available via EURACTIV. https://www.euractiv.com/section/development-policy/ interview/sue-lautze-south-sudan-needs-meaningful-peace/. Accessed 19 July 2021

Evening Standard (2007) Mr Benn where has our £400m Afghan Aid Money gone?, 20 January 2007

Fawcett J, Tanner V (1999) Birth of the Aid Juggernaut in Former Yugoslavia (1991-2): Humanitarian plot or unintended consequences? A report to USAID's Office of Foreign Disaster Assistance, USAID, Washington DC

Feher M (2000) Powerless by design: the age of the international community. Duke University Press, Durham/London. https://doi.org/10.1215/97808223 97694

Feher M (2004) Constancy in context. Winsconson Int Law J 24(3):773-784

Foley C (2008) The thin blue line: how humanitarianism went to war. Verso, London

Foley C (2017) The protection of civilians by UN peacekeepers: saving succeeding generations. Cambridge University Press, Cambridge. https://doi.org/10.1017/ 9781108236126

Foxley T (2007) Why the PRTs must be reviewed. Stockholm International Peace Research Institute Project Paper (internal document)

Gibbs D (2009) First do no harm: humanitarian intervention and the destruction of Yugoslavia. Vanderbilt University Press, Nashville. https://doi.org/10.2307/j. ctv16h2n88

Giradet E (1993) Public opinion, the media and humanitarianism. In: Weiss T, Minear L (eds) Humanitarianism across Borders: Sustaining Civilians in Times of War. Lynne Rienner, Boulder, pp 39-55

Goodhand J (2013) Contested boundaries: NGOs and civil-military relations in Afghanistan. Central Asian Survey 32(3):287-305. https://doi.org/10.1080/02 634937.2013.835211

Gordon S (2000) Recipe for making safe areas unsafe. In: Gordon S, Toase F (eds) Aspects of Peacekeeping. Routledge, London, pp 213-230

Gordon S (2004) Military - humanitarian relationships and the invasion of Iraq (2003): reforging certainties? J Humanitarian Assistance https://sites.tufts.edu/ jha/archives/101. Accessed 27 July 2018

Gow J (1997) Triumph and a lack of will: international diplomacy and the Yugoslav War. Columbia University Press, New York

Hammerstad A (2014) The Rise and Decline of a Global Security Actor: UNHCR, Refugee Protection and Security. Oxford University Press, Oxford. https://doi. org/10.1093/acprof:oso/9780199213085.001.0001

Hartmann F (2015) Le Sang de la realpolitik, l'affaire Srebrenica. Don Quichotte, Paris

Havel V (1999) Moi aussi je me sens albanais. Le Monde, 29 April 1999

Hehir A (2008) Humanitarian intervention after Kosovo: Iraq, Darfur and the record of global societies. Palgrave Macmillan, Basingstoke. https://doi.org/1 $0.1057 / 9780230584105$

Hehir B (1998) Military intervention and national sovereignty: recasting the relationship. In: Moore J, Ignatieff M (eds) Hard Choices: Moral Dilemmas in Humanitarian Intervention. Rowman \& Littlefield, Oxford, pp 29-54

Hess P (2003) Rumsfield declares war over in Afghanistan, United Press International Available via UPI. http://www.upi.com/Archives/2003/05/01/ Rumsfeld-declares-war-over-in-Afghanistan/191105176160. Accessed 23 Apr 2017

Hochschild F (2004) It is better to leave, we can't protect you. J Refugee Stud 17(3):286-300. https://doi.org/10.1093/jrs/17.3.286 
Hoffman S (1996) Intervention in the former Yugoslavia. In: Hoffman S (ed) The Ethics and Politics of Humanitarian Intervention. University of Notre Dame Press, Notre Dame, pp 38-60

Hofman M (2014) The Evolution from Integrated Missions to 'Peace Keepers on Steroids': How Aid by Force Erodes Humanitarian Access. Glob Responsibility Protect 6(S2):246-263. https://doi.org/10.1163/1875984X-00602009

Holbrooke R (1999) To end a war. Modern Library, New York

Hopgood S (2015) Interview: Stephen Hopgood. Available via E-IR. www.e-ir. info/2015/07/03/interview-stephen-hopgood. Accessed 29 Dec 2020

Hopgood S (2019) When the music stops: humanitarianism in a post-liberal world order. J Humanitarian Aff 1(1):4-14. https://doi.org/10.7227/JHA.002

Human Rights Watch (1999) Leave none to tell the story: genocide in Rwanda. HRW, New York

Hunt J (2019) Yemen crisis won't be solved by UK arms exports halt. Available via POLITICO. https://www.politico.eu/article/conflict-war-un-yemen-crisis-wontbe-solved-by-uk-arms-exports-halt/. Accessed 20 July 2021

Hutchinson J (1996) Champions of charity: war and the rise of the Red Cross. Westview Press, Boulder

Huysmans J (2002) Shape-shifting NATO: humanitarian action and the Kosovo refugee crisis. Rev Int Stud 28(3):599-618. https://doi.org/10.1017/S026021 0502005995

Inter-Agency Standing Committee (2014) Inter-agency humanitarian evaluation of response to conflict in South Sudan. Final Terms of Reference. IASC, Geneva

Inter-Agency Standing Committee (n.d.) Key messages: the IASC's transformative agenda. Available via IASC. https://interagencystandingcommittee.org/ system/files/legacy_files/KM\%20and\%20FAQ\%20on\%20Transformative\%20A genda\%20final.docx. Accessed 20 July 2021

Internal Displacement Monitoring Committee (2014) Greater humanitarian and development efforts needed to meet IDPs' growing needs. IDMC, Geneva

International Committee of the Red Cross (2000) Fourth workshop on protection on human rights and humanitarian organisations: the challenges of complementarity (internal document). ICRC, Geneva

International Crisis Group (1999) War in the Balkans: consequences of the Kosovo conflict and future options for Kosovo and the region. Balkans Report N ${ }^{\circ} 61$. ICG, Brussels

International Crisis Group (2006) Countering Afghanistan insurgency: no quick fixes. Asia Report No. 123. ICG, Brussels

International Herald Tribune (1994) Rwandan Officials escape to Safe Zone, 16/17 July 1994

International Monetary Fund (2003) Islamic state of Afghanistan: rebuilding a macroeconomic framework for reconstruction and growth. Country Report No. 03/299. IMF, Washington DC

International Security Assistance Force (2012) Provincial Reconstruction Team (PRT) Handbook (on file with the author)

Irish Times (2001) We will not walk away after conflict, says Blair. Irish Times, 9 October 2001

Jackson A (2010) Nowhere to turn: the failure to protect civilians in Afghanistan Oxfam International, Oxford

Jean F (1993) Introduction. In: Francois J (ed) Life, Death and Aid: the Medecins Sans Frontieres report on World Crisis Intervention. Routledge, London, pp $1-10$

Jehl D (1994) Officials told to avoid calling Rwanda Killings 'Genocide'. New York Times, 10 June 1994

Johnson T, Mason C (2007) Understanding the Taliban and Insurgency in Afghanistan. Orbis 51(1):71-89. https://doi.org/10.1016/j.orbis.2006.10.006

Jones DB (1997) NGOs in complex emergency project. Conflict Analysis and Development Unit. London School of Economics and Political Science, London

Kampfner J (2003) Blair's wars. Simon \& Schuster UK Ltd., London

Kaplan R (1993) Balkan ghosts. St. Martin's Press, New York

Kaufman M (1999) The dangers of letting a president read. New York Times, 22 May 1999

Keen D (1996) Organised chaos: not the new world we ordered. World Today 52(1):14-17

Keen D (1997) A rational kind of madness. Oxford Dev Stud 25(1):67-75. https:// doi.org/10.1080/13600819708424122

Keen D (1999) 'Who is it between?' 'ethnic war' and rational violence. In: Allen T, Seaton J (eds) The Media of Conflict: War Reporting and Representations of Ethnic Violence. Zed Books, London
Keen D (2000a) Going to war: how rational is it? In: Carbonnier G, Fleming S (eds) War, Money and Survival: Forum (2). ICRC, Geneva, pp 28-31

Keen D (2000b) Incentives and disincentives for violence. In: Berdal M, Malone DM (eds) Greed and Grievance: Economic Agendas in Civil Wars. Lynne Reinner Publishers, Boulder, pp 19-42

Keen D (2000c) War and peace: what's the difference? Int Peacekeeping 7(4):122. https://doi.org/10.1080/13533310008413860

Keen D (2005) Liberalization and conflict. Int Pol Sci Rev 26(1):73-89

Keen D (2009a) Occasional Paper 9: Economic Initiatives to Tackle Conflict: Bringing Politics Back. Crisis States Research Centre, LSE Development Studies Institute (DESTIN), London

Keen D (2009b) Security and protection. KEYNOTE PAPER. International Conference: 'Protecting People in Conflict and Crisis: Responding to the Challenges of a Changing World'. Available via REFUGEE STUDIES CENTRE. https://www.rsc.ox.ac.uk/files/files-1/dp-security-protection-2009.pdf. Accessed 19 July 2021

Kent G (2003) Humanitarian agencies, media and the war against Bosnia: 'neutrality' and framing moral equalisation in a genocidal war of expansion. $J$ Humanitarian Assistance https://sites.tufts.edu/jha/files/2011/04/a141.pdf. Accessed 25 June 2015

Ki-Moon B (2016) One humanity: shared responsibility: report of the SecretaryGeneral for the World Humanitarian Summit, advance unedited draft. United Nations, Geneva

Labonte M (2003) Norm entrepreneurship, management, and humanitarian politics: the false paradox of balancing between neutrality and advocacy. Paper presented at the 2003 Annual Conference of the International Studies Association, Portland 26 February - 1 March 2003

Leader N, Atmar H (2004) Political projects: reform, aid and the state in Afghanistan. In: Donini A, Niland N, Wermenster K (eds) Nation-Building Unravelled? Aid, Peace and Justice. Kumarian Press Inc, Bloomfield, pp 166-186

Leader N, Macrae J (2001) Apples, Pears and Porridge: The Origins and Impact of the Search for 'Coherence' between Humanitarian and Political Responses to Chronic Political Emergencies. Disasters 25(4):290-307.

Le Pape M, Bradol J-H (2017) Humanitarian aid, genocide and mass killings: Medecins sans Frontieres, the Rwandan experience, 1982-97. Manchester University Press, Manchester

Lockhart C (2011) Struggling for Government Leadership: The Relationship between Afghan and International Actors in Post-2001 Afghanistan. In: Mayall J, De Oliveira, R S (eds) The New Protectorates: International Tutelage and the Making of States. Hurst and Company, London. pp. 259-80

Lorenzi M (1998) Entretiens avec Cornelio Sommaruga: Le CICR, le coeur et la raison. Favre, Lausanne.

Lowell M, Crisp J, Mayne A (1994) Working in a War Zone: Review of UNHCR Operations in the Former Yugoslavia. UNHCR Evaluation Unit, Geneva Available via UNHCR http://www.unhcr.org/uk/research/evalreports/3bd41 feb4/working-war-zone-review-unhcrs-operations-former-yugoslavia.html. Accessed 22 Apr 2017

Luttwak E (1999) Give War a Chance. Foreign Aff 78(4):36-44. https://doi.org/1 $0.2307 / 20049362$

Macrae J, Burton J, Lebas J (1996) Origins of unease: setting the context of current ethical debate. Paper presented at seminar Forum on Ethics in Humanitarian Aid, Dublin 9-10 December 1996

Major J (1994) Letter to head of Oxfam David Bryer, 10 May 1994. Obtained via a Freedom of Information Request

Major J (1999) John major: the autobiography. Harper Collins, London

Manchester W (1989) The last lion: Winston Spencer Churchill: Alone 1932-1940. Bantam, New York

Martone G (2006) Life with dignity: what is the minimum standard? In: Bayevsky AF, Fitzpatrick J, Helton A (eds) Human Rights and Refugees, Internally Displaced Persons and Migrant Workers. Marinus Nijhoff Publishers, Boston, pp 129-144

McHugh G, Gostelow L (2004) Provincial reconstruction teams and humanitarianmilitary relations in Afghanistan. Save the Children, London

McKernan B (2018) Yemen: up to 85,000 young children dead from starvation. The Guardian, 21 November 2018

Melvern $L$ (2004) The West did intervene in Rwanda, on the wrong side. The Guardian, 5 April 2004

Mendiluce J-M (1994) War and disaster in the former Yugoslavia: the limits of humanitarian action. In: US Committee for Refugees (ed) World refugee survey 1994. U.S Committee for Refugees, Washington DC, pp 10-19 
Merat A (2019) The Saudis couldn't do it without us': the UK's true role in Yemen's deadly war. The Guardian, 18 June 2019

Minear L, Smilie I (2004) The charity of nations: humanitarian action in a calculating world. Kumarian Press Inc, Bloomfield

Mooney E (1995) Presence, ergo protection? UNPROFOR, UNHCR and the ICRC in Croatia and Bosnia-Hercegovina. Int J Refugee Law 7(3):407-435. https://doi. org/10.1093/ijrl/7.3.407

Moorehead C (1998) Dunant's dream: war, Switzerland and the history of the Red Cross. Harper Collins, London

Morison E (1954) The Letters of Theodore Roosevelt. Harvard University Press, Cambridge

Morris N (1998a) Humanitarian aid and neutrality. Available via UNIVERSITY OF ESSEX https://www.essex.ac.uk/rightsinacutecrisis/report/morris. htm\#footnotes. Accessed 23 Apr 2017

Morris N (1998b) The crisis in Kosovo. UNHCR Office of the Special Envoy for the former Yugoslavia, 22 September 1998 (internal document)

Morris N (1999) Origins of a Crisis. Refugees 3(116):18-19

Morris N (2003) Humanitarian intervention in the Balkans. In: Welsh J (ed) Humanitarian Intervention and International Relations. Oxford University Press, Oxford, pp 98-119. https://doi.org/10.1093/0199267219.003.0006

Morris N (2004) Humanitarian Intervention in the Balkans. In: Welsh J (ed) Humanitarian Intervention and International Relations. Oxford University Press, Oxford. pp. 98-119

Morris N (2007) The Balkans: the limits of humanitarian action. In: Minear L, Smith $\mathrm{H}$ (eds) Humanitarian Diplomacy: Practitioners and their Craft. United Nations University Press, Tokyo, pp 347-371

Mowjee T (2006) Humanitarian Agenda 2015: Sudan Country Study. Feinstein International Centre, Medford

Mundy M (2017) Empire of information: the war on Yemen and its agricultural sector. Available via LSE BLOGS. https://blogs.lse.ac.uk/mec/2017/06/19/ empire-of-information-the-war-on-yemen-and-its-agricultural-sector/. Accessed 10 July 2021

NATO (1999) Press Conference by NATO Secretary General Javier Solana and General Wesley K. Clark, SACEUR, 1 April 1999. Available via NATO. http:// www.nato.int/kosovo/press/p990401c.htm. Accessed 23 Apr 2017

Nicoll A (2002) Troops' role is to help interim rulers. Financial Times, 11 January 2002

O'Brien P (2003) PRTs — guaranteeing or undermining a secure future for Afghanistan? Forced Migr Rev 18:38-39

O'Brien P (2005) Rights-based responses to aid politicization in Afghanistan. In: Gready P, Ensor J (eds) Reinventing Development? Translating Rights-based pproaches from Theory into Practise. Zed Books, London/New York, pp 201-232

O'Brien P, Barker P (2003) Old questions needing new answers: a fresh look at security needs. In: Sedra M (ed) Confronting Afghanistan's Security Dilemma: Reforming the Security Sector. Bonn International Centre for Conversion, Bonn, pp 17-22

Ogata S (2005) The turbulent decade: confronting the refugee crises of the 1990s. Norton, New York

Organisation for Security and Cooperation in Europe (1999) Human Rights in Kosovo: As Seen, As Told, Volume II. OSCE, Vienna

Owen D (2013) Bosnia-Herzegovina : the Vance/Owen Peace Plan. Liverpool University Press, Liverpool

Oxfam (2015) British aid and British arms - a coherent approach to Yemen? Oxfam Briefing Note. Available via OXFAM POLICY PRACTICE. https://policypractice.oxfam.org.uk/publications/british-aid-and-british-arms-a-coherent-a pproach-to-yemen-577040. Accessed on 1 Aug 2019

Pekmez J (2001) The intervention by the international community and the rehabilitation of Kosovo, Centre for Applied Studies in International Negotiations, Geneva

Perlez J (2000) Allies split on Kosovo: spiralling violence divides US and NATO. International Herald Tribune, 14 March 2000

Pettifer J (2012) The Kosovo liberation army: underground war to Balkan insurgency, 1948-2001. Hurst \& Co., London

Piiparinen T (2007) A clash of mindsets? An Insider's account of provincial reconstruction teams. Int Peacekeeping 14(1):143-157. https://doi.org/10.1 080/13533310601114350

Power S (2002) A problem from hell: America and the age of genocide. Basic Books, New York

Prendergast J (1997) Crisis response: humanitarian band aids in Sudan and Somalia. Pluto Press, London/Chicago
Priest D (1999) Risk and restraint: why the apaches never flew in Kosovo. Washington Post, 29 December 1999

Prunier G (1995) The Rwanda crisis 1959-1994: history of a genocide. Hurst \& Co., London Pugh M (2000) Civil-military relations in Kosovo: an emerging hegemony? Secur Dialogue 31(2):229-242. https://doi.org/10.1177/0967010600031002008

Purdum T, French H (2002) US makes pledge for $\$ 300$ million in Aid to Afghans. New York Times, 21 January 2002

Riddell RC (2007) Does foreign aid really work? Oxford University Press, Oxford

Rieff D (1996) Slaughterhouse: Bosnia and the Failure of the West. Touchstone, New York

Rieff D (1997) Charity on the rampage. Foreign Aff 76(1):132-138. https://doi. org/10.2307/20047914

Rieff D (2002) A bed for the night: humanitarianism in crisis. Simon and Schuster, New York

Roberts A (1993) Humanitarian war: military intervention and human rights. Int Aff 69(3):429-449. https://doi.org/10.2307/2622308

Roberts A (1999) NATO's Humanitarian war over Kosovo. Survival 41(3):102-123. https://doi.org/10.1080/00396339912331342943

Rose, M (1995) The UN can only do so much in Bosnia. The Guardian, 3 May 1995

Rubin B, Stoddard A, Hamidzada H, Farhadi A (2004) Building a new Afghanistan: the value of success, the cost of failure. New York University, New York

Rufin J-C (1993) The paradoxes of armed protection. In: Francois J (ed) Life, Death and Aid: the Medecins Sans Frontieres report on World Crisis Intervention. Routledge, London, pp 111-123

Save the Children (2019) Stop the war on children. Save the Children, London

Schoenberger-Orgad M (2007) Communicating Strategically: Public Relations and Organisational Legitimacy. PhD Thesis, University of Waikato, Hamilton

Scott-Smith T (2016) Humanitarian dilemmas in a mobile world. Refugee Surv Q 35(2):1-21. https://doi.org/10.1093/rsq/hdw001

Shawcross W (2000) Deliver us from evil: warlords and peacekeepers in a world of endless conflict. Bloomsbury Publishing Plc, London

Slim H (1997) International humanitarianism's engagement with civil war in the 1990s: a glance at evolving practice and theory. J Humanitarian Assistance http://repository.forcedmigration.org/show_metadata.jsp?pid=fmo:2719. Accessed 27 July 2018

Slim H (2001) Violence and humanitarianism: moral paradox and the protection of civilians. Secur Dialogue 32(3):325-339. https://doi.org/10.1177/096701 0601032003005

Slim H (2004) Protecting civilians: putting the individual at the humanitarian centre. In: UNOCHA (ed) The Humanitarian Decade: Challenges for Humanitarian Assistance in the Last Decade and into the Future. Vol II: General Assembly Resolution 46/182: The Development of Practice, Principles and the Humanitarian Framework. UNOCHA, New York, pp 154-170

Stapleton B (2003a) A British agencies Afghanistan group briefing paper on the development of joint regional teams in Afghanistan. Refugee Council, London

Stapleton B (2003b) The provincial reconstruction team plan in Afghanistan: a new direction? ACBAR, Kabul

Stapleton B (2007) A means to what end? Why PRTs are peripheral to the bigger political challenges in Afghanistan. J Mil Strateg Stud 10(1):1-49

Stapleton B, Keating M (2016) Afghanistan: opportunity in crisis series No. 10: Military and Civilian Assistance to Afghanistan 2001-14: An Incoherent Approach. Chatham House, London

Stewart F (ed) (2008) Horizontal inequalities and conflict: understanding group violence in multi-ethnic societies. Palgrave Macmillan, Basingstoke

Stockton N (2002) Strategic coordination in Afghanistan, issue paper series. Afghanistan Research and Evaluation Unit, Kabul

Stockton N (2004) Afghanistan, war, aid and international order. In: Donini A, Niland N, Wermenster K (eds) Nation-Building Unravelled? Aid. Peace and Justice. Kumarian Press Inc., Bloomfield, pp 9-38

Stoddard A (2006) Humanitarian alert: NGO information and its impact on US foreign policy. Kumarian Press, Bloomfield

Straw J (2001) Building will follow the Bombing. The Guardian, 25 October 2001

Tanguy J (2000) When intervening in the name of humanity, Be Cautious. Public Aff Rep 41(1):8-10

Temin J (2018) From independence to civil war: atrocity prevention and US policy toward South Sudan. Simon-Skjodt Center for the Prevention of Genocide, Washington D.C

Terry F (1998) The paradoxes of humanitarian aid. Agenda 5(2):135-146. https:// doi.org/10.22459/AG.05.02.1998.01 
Terry F (2002) Condemned to Repeat? The Paradox of Humanitarian Action. Cornell University Press, New York

The Guardian (2001a) Speech by Foreign Secretary Jack Straw to the International Institute of Strategic Studies. Available via THE GUARDIAN. http://www.theguardian.com/politics/2001/oct/22/britainand911. september11. Accessed 23 Apr 2017

The Guardian (2001b) Full text of Blair's speech. Available via THE GUARDIAN. http://www.theguardian.com/world/2001/oct/08/september11.usa5. Accessed 23 Apr 2017

The Guardian (2016) The Guardian view on Yemen: stop helping the killing, 6 November 2016

The Independent (1992) NATO may send in 100,000 troops to cover aid convoy, 7 August 1992

Thier A (2006) Afghanistan. In: Durch W (ed) Twenty-first-century peace operations. United States Institute for Peace \& The Henry L. Stimson Centre, Washington DC, pp 467-572

Tomlinson R (2000) Reversing the Downward Spiral: Exploring Cultural Dissonance between the Military and NGOs on Humanitarian Operations. Dissertation, Royal College of Science, Cranfield University, Cranfield.

United Nations (1996) The United Nations and Rwanda 1993-1996. UN Department of Public Information, New York

United Nations (2014) Special Report of the Secretary-General on the Review of the African Union-United Nations Hybrid Operation in Darfur, S/2014/138

United Nations (2015) Special Report of the Secretary-General on the African Union-United Nations Hybrid Operation in Darfur S/2015/163

United Nations (2017) Report of the Secretary-General on the African UnionUnited Nations Hybrid Operation in Darfur S/2017/1113

United Nations Office for the Coordination of Humanitarian Assistance (2015) Report of the inter-agency humanitarian evaluation (IAHE) of the Response to the Crisis in South Sudan. Final Evaluation Report. IASC, Juba

United Nations Panel of Experts (2017) Letter dated 13 April 2017 from the Panel of Experts on South Sudan established pursuant to Security Council resolution 2206 (2015) addressed to the President of the Security Council. S/ 2017/326

United Nations Panel of Experts on South Sudan (2015) Letter dated 21 August 2015 from the Panel of Experts on South Sudan established pursuant to Security Council resolution 2206 (2015) addressed to the President of the Security Council. S/2015/656

United Nations Panel of Experts on South Sudan (2016) Letter dated 22 January 2016 from the Panel of Experts on South Sudan established pursuant to Security Council resolution 2206 (2015) addressed to the President of the Security Council. S/2016/70

United States Office of the Deputy Assistance Secretary of Defense for Middle East/Africa Region (1994) Discussion Paper: Rwanda. Available via GEORGE WASHINGTON UNIVERSITY. http://www.gwu.edu/ nsarchiv/NSAEBB/NSA EBB53/rw050194.pdf. Accessed 19 July 2021

United States State Department (2000) Interagency review of US government civilian and humanitarian transition programs. US State Department, Washington DC

Uvin P (1993) Do as i do, not as i say: the limits of political conditionality. Eur J Dev Res 5(1):63-84. https://doi.org/10.1080/09578819308426579

Uvin P (1998) Aiding Violence: The Development Enterprise in Rwanda. Kumarian Press, West Hartford

Uvin P, Biagiotti I (1996) Global governance and the "new" political conditionality. Glob Governance 2(3):377-400

Vaux T (2001) The Selfish Altruist. Earthscan, London

Vaux T (2015) Inter-agency humanitarian evaluation of response to conflict in South Sudan, evaluation report draft 1. Available via HUMAN SECURITY. https://www.humansecurity.org.uk/wp-content/uploads/SSudanIAHEVaux.pdf. Accessed on 25 July 2018

Vaux T (2017) Trumped-up Aid and the Challenge of Global Poverty. CreateSpace Independent Publishing Platform, Scotts Valley

Vrijzinnig Protestantse Radio Omroep (2015) 2doc: why srebrenica had to fail. Available via VPRO. http://www.vpro.nl/programmas/2doc/2015/waaromsrebrenica-moest-vallen0.html. Accessed 27 July 2016

Weissman F (2004) Military Humanitarianism: a deadly confusion. Médecins sans Frontières. Available via MSF-CRASH. http://www.msf-crash.org/drive/e7aafw-2004-militaro-humanitaire-une-confusion-mortelle-_uk-art-p.5_.pdf. Accessed 23 Apr 2017
Wheeler N (2000) Saving strangers: Humanitarian Intervention in International Society. Oxford University Press, Oxford. https://doi.org/10.1093/0199253102. 001.0001

White House (2002) Press Briefing by Ari Flesicher, 25 January 2002. Available via GEORGE W BUSH WHITE HOUSE ARCHIVES. https://georgewbushwhitehouse.archives.gov/news/releases/2002/01/20020128-11.html. Accessed 27 June 2015

Young K (2001) UNHCR and ICRC in the former Yugoslavia: Bosnia-Herzegovina. Int Rev Red Cross 83(843):781-806

Zurcher C (2012) Conflict, state fragility and aid effectiveness. Confl Secur Dev 12(5):461-480. https://doi.org/10.1080/14678802.2012.744180

Zurcher C, Bohnke J, Koehler J (2015) Assessing the impact of development cooperation in North East Afghanistan 2007-2013. Final Report. Federal Ministry for Economic Cooperation and Development, Berlin

\section{Publisher's Note}

Springer Nature remains neutral with regard to jurisdictional claims in published maps and institutional affiliations.

\section{Submit your manuscript to a SpringerOpen ${ }^{\circ}$ journal and benefit from:}

- Convenient online submission

- Rigorous peer review

- Open access: articles freely available online

High visibility within the field

- Retaining the copyright to your article

Submit your next manuscript at $\boldsymbol{\nabla}$ springeropen.com 